\title{
Ras isoform-specific expression, chromatin accessibility, and signaling
}

\author{
Ruth Nussinov $^{1,2}$ (D) Mingzhen Zhang ${ }^{1} \cdot$ Ryan Maloney ${ }^{1} \cdot$ Hyunbum Jang ${ }^{1}$
}

Received: 11 May 2021 / Accepted: 29 June 2021 / Published online: 31 July 2021

(C) The Author(s) 2021

\begin{abstract}
The anchorage of Ras isoforms in the membrane and their nanocluster formations have been studied extensively, including their detailed interactions, sizes, preferred membrane environments, chemistry, and geometry. However, the staggering challenge of their epigenetics and chromatin accessibility in distinct cell states and types, which we propose is a major factor determining their specific expression, still awaits unraveling. Ras isoforms are distinguished by their C-terminal hypervariable region (HVR) which acts in intracellular transport, regulation, and membrane anchorage. Here, we review some isoform-specific activities at the plasma membrane from a structural dynamic standpoint. Inspired by physics and chemistry, we recognize that understanding functional specificity requires insight into how biomolecules can organize themselves in different cellular environments. Within this framework, we suggest that isoform-specific expression may largely be controlled by the chromatin density and physical compaction, which allow (or curb) access to "chromatinized DNA." Genes are preferentially expressed in tissues: proteins expressed in pancreatic cells may not be equally expressed in lung cells. It is the rule - not an exception, and it can be at least partly understood in terms of chromatin organization and accessibility state. Genes are expressed when they can be sufficiently exposed to the transcription machinery, and they are less so when they are persistently buried in dense chromatin. Notably, chromatin accessibility can similarly determine expression of drug resistance genes.
\end{abstract}

Keywords KRAS $\cdot$ HRAS $\cdot$ NRAS $\cdot$ K-RAS4A $\cdot$ K-RAS4B $\cdot$ Gene accessibility $\cdot$ Signaling $\cdot$ Inhibitor

\section{Introduction}

Quantifying Ras isoform-specific expression in distinct tissues has been challenging. Here, we suggest that a key factor determining their cell-specific levels is their epigenetics and chromatin accessibility status. Chromatin accessibility relates to the local density level of proteins including histones, transcription factors, chromatin-modifying enzymes, and chromatin-remodeling complexes on the DNA. Their depletion at cis-regulatory elements commonly points to candidate

Ruth Nussinov

NussinoR@mail.nih.gov

1 Computational Structural Biology Section Leidos Biomedical Research, Inc., Frederick National Laboratory for Cancer Research in the Laboratory of Cancer Immunometabolism National Cancer Institute, 1050 Boyles St, Frederick, MD 21702, USA

2 Department of Human Molecular Genetics and Biochemistry, Sackler School of Medicine Tel Aviv University, 69978 Tel Aviv, Israel genomic regions which may be available for transcription (Minnoye et al. 2021). Post-translational modifications (PTMs) of chromatin, such as DNA methylation, and histone methylation and acetylation, are dynamic, varying across cell states and types and correlating with chromatin accessibility and gene expression. The dynamic density levels make profiling of accessibility an extremely difficult task (Ashwin et al. 2019; Barth et al. 2020; Wachsmuth et al. 2016). An added complexity is the interpretation of the data as it relates to enhancer-promoter proximity and functional transcription factor binding (Minnoye et al. 2021). As we discuss below, these complexities combine with additional ones underscoring the challenge of quantitative studies of Ras isoform-specific expression.

Here, we describe isoform-specific activities and review experimental observations from a structural dynamic standpoint. This conformational perspective of isoform-specific activities mimics nature: biomolecules are not static sculptures. Molecular behavior, which dominates the structure-function paradigm, is shaped by biomolecules which are always switching between a variety of structures with varying 
energies, with the most populated being those which are energetically most favored. This dynamic (Kumar et al. 2000; Tsai et al. 1999) behavior can be described by the free energy landscape (Frauenfelder et al. 1991). The populations of the conformational species are influenced by multiple factors, including sequence alterations, which dictate specific interactions. Thus, with different sequences and chemistries (charge, hydrophobicity) and distinct combinations of hydrophobic PTMs in the hypervariable C-terminal tails (Fig. 1), the isoforms present different favored interactions with membrane lipids and protein partners.

Our views are influenced by concepts from physics and chemistry. We believe that molecular fluctuations are harnessed for life (Nussinov 2016; Wei et al. 2016) and that biomolecules must be described statistically, not statically. Understanding functional specificity requires insight into how biomolecules can organize themselves and their assemblies in different cellular environments, including molecular
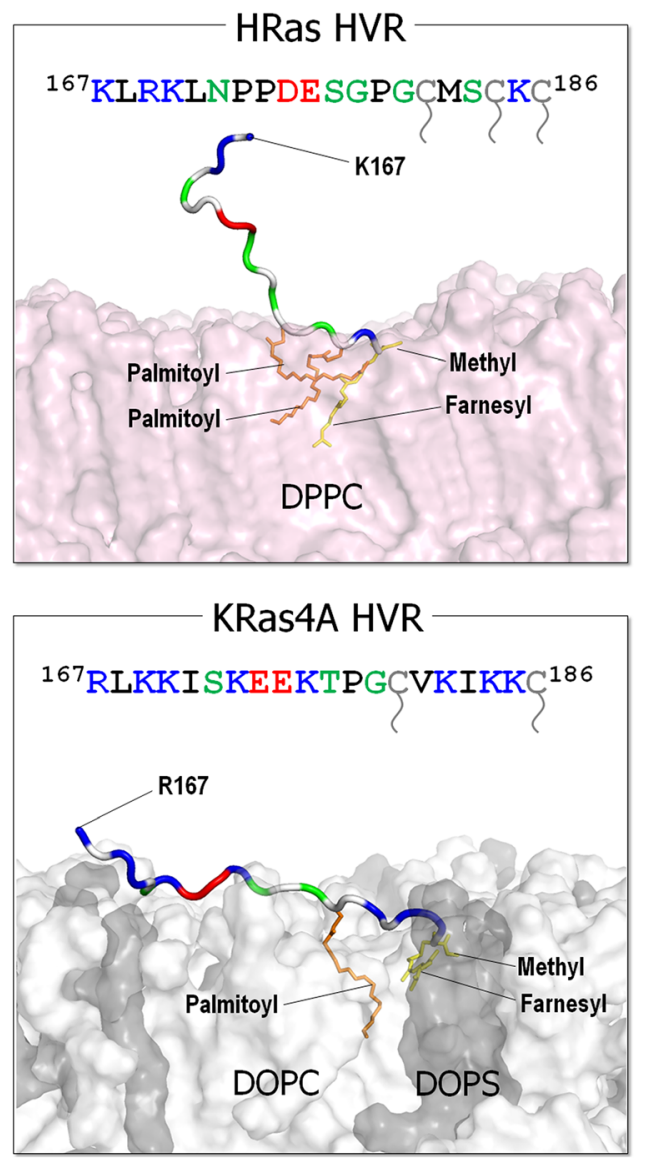

Fig. 1 The sequences of C-terminal hypervariable regions (HVRs, residues 167-185/186) of the Ras isoforms and the modeled HVR structures with the post-translational modifications (PTMs) representing their preferred membrane interactions. The modeled HRas and NRas HVR peptides preferentially bind the zwitterionic DPPC or DOPC bilayers in the gel or liquid phases, while the KRas HVR peptides anchor to the anionic DOPC/DOPS bilayer in the liquid phase. In the HVR sequence, basic residues (positively charged) are colored in blue, acidic residues concentrations (e.g., of scaffolding proteins, as was shown for galectin-1 (Blazevits et al. 2016)). It is also manifested by the distinct segregations into nanoclusters, and the isoform dynamics between the substructures where they congregate and their movements in the plasma membrane into-and out ofthe membrane domains (Nussinov et al. 2019b).

\section{Background information on Ras}

\section{Ras isoforms, structure, and biology}

Ras proteins control cell proliferation pathways, cell growth and division (Lavoie et al. 2020; Nussinov et al. 2020b; Smith et al. 2020). Three RAS genes lead to four proteins, HRas, NRas, and splice variants KRas4A and KRas4B. The incidence of mutated $R A S$ genes differs among human cancers: $K R A S$ is the most highly mutated isoform ( $85 \%)$, followed by
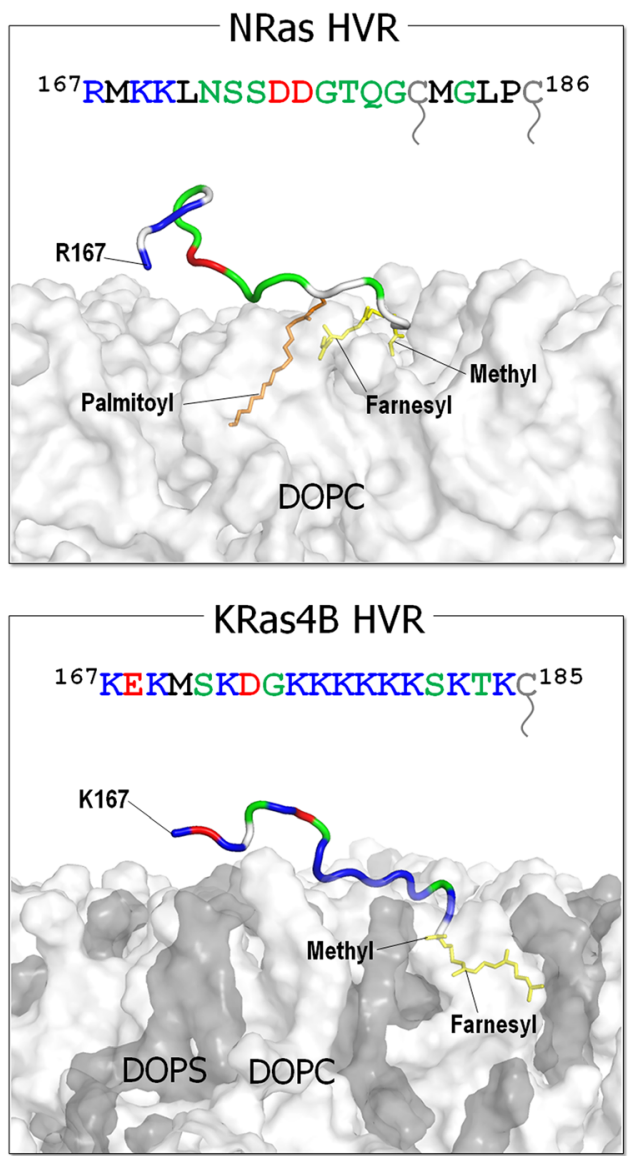

(negatively charged) are colored in red, hydrophobic residues are colored in black, and polar and glycine residues are colored in green. The prenylated Cys residues are colored in gray with a tail mark. In the HVR cartoon, the same colors are used, except the hydrophobic residues colored in white. The farnesyl and palmitoyl groups are shown as yellow and orange sticks, respectively. In the surface representation of lipid bilayer, pink, white, and gray surfaces denote DPPC, DOPC, and DOPS, respectively 
NRAS (11\%), and HRAS (4\%). They predominate in different cancer types and the distributions of the mutations differ as well (Cox et al. 2014; Hobbs et al. 2016; Li et al. 2018a; Prior et al. 2012). Sequence comparisons indicate that the catalytic domains of the isoforms (residues 1-166) are almost identical. Binding to exchange factors exchanges GDP by GTP activating the Ras isoforms; binding to GTPase-activating proteins (GAPs) deactivates them (Tsai et al. 2015; Vigil et al. 2010). When activated, Ras proteins bind and activate their effectors, initiating their respective signaling pathways, primarily mitogen-activated protein kinase (MAPK) via Raf/MEK/ ERK (MEK, mitogen-activated protein kinase kinase; ERK, extracellular signal regulated kinase) and PI3K/AKT/mTOR (PI3K, phosphatidylinositol 3-kinase; AKT, protein kinase B; mTOR, mechanistic target of rapamycin) phosphorylation cascades. Both signaling pathways feed into the cell cycle, together leading to cell proliferation (Nussinov et al. 2017).

Over 150 experimentally determined structures of the catalytic domain have been deposited in the structural database. In contrast, the 22-23 residue C-terminal tail which constitutes the hypervariable region (HVR) is disordered, precluding crystallization. However, its populated conformations have been sampled by NMR and molecular dynamics (MD) simulations (Chavan et al. 2015a). Membrane anchorage, executed by the tails, is required for Ras activation, with the tails' hydrophobic PTMs docking at favored membrane environments (Fig. 1). The HVRs are farnesylated, proteolyzed, and carboxyl methylated. In addition, NRas, HRas, and KRas4A cysteines are palmitoylated. These PTMs stabilize the anchorage. Lacking a palmitoyl, KRas4B attachment to negatively charged membranes is assisted by a lysine polybasic stretch $\left({ }^{175} \mathrm{KKKKKK}^{180}\right)$. The covalent palmitoylation thioester modification linkages are reversible; the farnesyl thioether linkages are not. The HVR of KRas4B can also be phosphorylated. The introduction of the large, negatively charged phosphoryl group dissociates KRas4B from the negatively charged plasma membrane (Bivona et al. 2006; Jang et al. 2015). The HVR of KRas4A resembles that of KRas4B: it is also highly positively charged, albeit not to the extent of KRas4B (Nussinov et al. 2016). Whereas the lysines are almost continuous in KRas4B, they are not in KRas4A and there are fewer of them (Tsai et al. 2015). KRas4A's pattern of PTMs varies as well and lies in-between NRas and KRas4B. Like NRas, KRas4A can have farnesyl and palmitoyl; however, with the palmitoyl thioester linkage being reversible, it may be hydrolyzed, resulting in KRas4A retaining only its farnesyl. This can explain KRas4A's acting as NRas (when the tail is farnesylated and palmitoylated) and as KRas4B (when the palmitoyl is hydrolyzed), thus NRas- and KRas4B-like cell transformation patterns (Tsai et al. 2015). Like the C181S NRas, a C180S mutation in KRas4A does not stop it from shuttling to the plasma membrane. However, in the absence of palmitoylation and diminished polybasic region as compared to KRas4B, KRas4A retains lower affinity for the plasma membrane (Chakrabarti et al. 2016; Muratcioglu et al. 2017; Nussinov et al. 2016). The HVR sequence and palmitoylation status also govern the isoforms' preferred plasma membranes (Eisenberg et al. 2011) (Fig. 2). The positively charged KRas HVR, but not HRas or NRas, strongly favors acidic disordered membranes (Fig. 1), making membrane composition an important consideration in isoform-specific signaling (Chavan et al. 2015b; Nussinov et al. 2018a). Isoform-specific HVR activities also include binding to membrane shuttling factors as in the case of phosphodiesterase- $\delta$ (PDE $\delta$ ) which shuttles KRas4B (Dharmaiah et al. 2016; Klein et al. 2019; Kuchler et al. 2018; Muratcioglu et al. 2017). NMR data and MD simulations of GDP-bound KRas4B suggest that the HVR obstructs access to the active site (Banerjee et al. 2016; Jang et al. 2016a), which apparently is not exhibited by other isoforms likely due to the absence of a sufficiently strong positive charge. Ras isoforms are also differentially ubiquitylated, which may affect their membrane attachment status (Ahearn et al. 2018; Dohlman and Campbell 2019; Hobbs et al. 2016; Sasaki et al. 2011). Activation-related effects include monoubiquitylation at Lys147, which increases the levels of KRas4B-GTP due to impaired GAP binding (Baker et al. 2013a; Sasaki et al. 2011), and HRas ubiquitylation at Lys117, which promotes GDP-GTP exchange (Abe et al. 2020; Baker et al. 2013b).

\section{Earlier discussions on Ras isoforms}

Several comprehensive reviews of Ras isoforms have been published in the last few years. These broadly discussed their different biochemical and biological (many cancer-related) roles, localization, sublocalization, and more. To avoid rereviewing the topics which were covered, we refer the reader to these recent excellent publications. These include subcellular localization and considering exploiting the membrane in therapeutics (Kattan and Hancock 2020; Zhou et al. 2018), mutational analysis and isoform signaling ( $\mathrm{Li}$ et al. 2018a; Munoz-Maldonado et al. 2019; Prior et al. 2020; Randic et al. 2021), subcellular localization and tumor growth (Garcia-Ibanez et al. 2020), Ras-ERK signaling (Zaballos et al. 2019) and MAPK inhibition (Heppner and Eck 2021; Ullah et al. 2021), isoform-specific differences in the effector binding regions (Nakhaeizadeh et al. 2016), and the recent contributions from the Mark Philips lab on KRas4A reversible palmitoylation and colocalization (Amendola et al. 2019) and on membrane association/colocalization (Zhou et al. 2020). Isoform signaling specificity at the membrane (Nussinov et al. 2018a), KRas mobility in the membrane (Nussinov et al. 2019b) and nanoclustering (Nussinov et al. 2019a) were also reviewed as well as genetic aspects of KRas signaling networks (Jinesh et al. 2018). Thus, below, we only briefly 


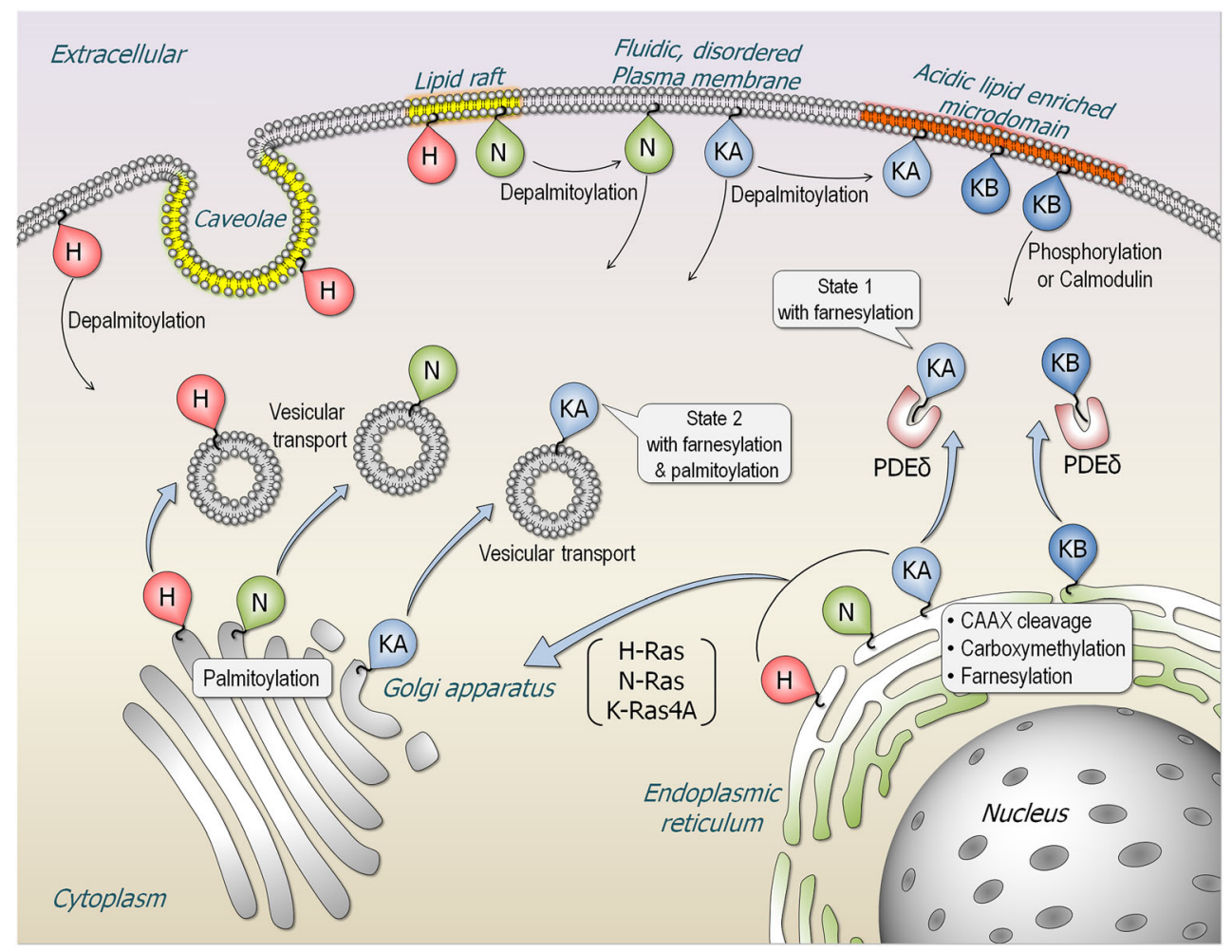

Fig. 2 Subcellular localization of Ras proteins. Ras isoforms, HRas, NRas, and two splice variants KRas4A and KRas4B terminate in a CAAX motif are cleaved, carboxymethylated, and farnesylated in the endoplasmic reticulum (ER). HRas, NRas, and KRas4A are further palmitoylated in the Golgi apparatus, while KRas4B traffics to the plasma membrane shuttled by phosphodiesterase- $\delta$ (PDE $\delta$ ). KRas $4 \mathrm{~A}$ in state 1 (only farnesylated) can also traffic to the plasma membrane via a similar mechanism as in KRas4B. After palmitoylation, HRas, NRas, and KRas4A in state 2 (with both farnesyl and palmitoyl modifications) are

touch on some of these aspects. Instead, we provide new views which we hope will help guide future research.

\section{Ras isoforms segregate into nanoclusters which favor distinct membrane composition: family members with similar tail chemistry can join}

GTP-bound Ras forms nanoclusters in the membrane. Nanoclustering is required for Ras signaling via the MAPK, but not PI3K $\alpha / \mathrm{AKT} / \mathrm{mTOR}$ pathways (Bandaru et al. 2019; Boriack-Sjodin et al. 1998; Cherfils and Zeghouf 2013; Hancock et al. 1989; Jang et al. 2016a; Jang et al. 2016b; Muratcioglu et al. 2017; Nussinov et al. 2018a; Nussinov et al. 2019b; Schmick et al. 2014; Zhou and Hancock 2015). The reason for this distinction is that for MAPK signaling, Raf kinase domains need to be activated. This requires their sideto-side (homo- or hetero-) dimerization (Freeman et al. 2013a; Freeman et al. 2013b; Jambrina et al. 2016; Lavoie et al. 2018; Rezaei Adariani et al. 2018; Tsai and Nussinov 2018; Udell et al. 2011; Varga et al. 2017; Verkhivker 2016; Yuan et al. 2018), which is not the case for PI3K $\alpha$ (Nussinov et al. 2018a; translocated to the plasma membrane via vesicular transport. HRas favors localization in the ordered caveolae and lipid rafts, and fluidic disordered (non-raft) regions of the plasma membrane. NRas can localize to cholesterol-rich lipid raft and non-raft regions. Depalmitoylation removes HRas and NRas from the plasma membrane. KRas4A in state 2 can localize to the non-raft region, while both KRas4A in state 1 and KRas4B highly localize to the acidic lipid enriched membrane microdomains. Phosphorylation of Ser181 or calmodulin extracts KRas4B from the plasma membrane

Nussinov et al. 2019a). The two kinase domains are contributed by two Raf molecules, with the Ras binding domain (RBD) of each Raf binding to the catalytic domain of an active Ras molecule (Fig. 3). This requires that Ras molecules either be in direct contact (Ras dimers) (Jang et al. 2020; Muratcioglu et al. 2020; Nan et al. 2015) or in spatial vicinity which can be achieved in sufficiently populated nanoclusters. Membrane anchored nanoclusters increase the probability of such favorable proximity (Nussinov et al. 2019a), and galectin dimers were proposed to scaffold Raf-effectors to further promote Ras nanoclustering (Blazevits et al. 2016). In this model, at high concentrations, galectin dimerizes in the cytoplasm and binds to two Raf's RBDs which are Ras-bound. The galectin-Raf complexes cooperatively nucleate Ras nanoclustering, thereby promoting dimerization of Raf's kinase domains. Computational modeling supported by experimental data suggested that cooperativity between KRas4B dimerization and Raf-1 (C-Raf) RBD-Ras binding may also emerge though the engagement of Raf-1's cysteine-rich domain (CRD) at the membrane (Jang et al. 2020). In this model, Raf-1's RBD-CRD can cooperatively support stable KRas4B 


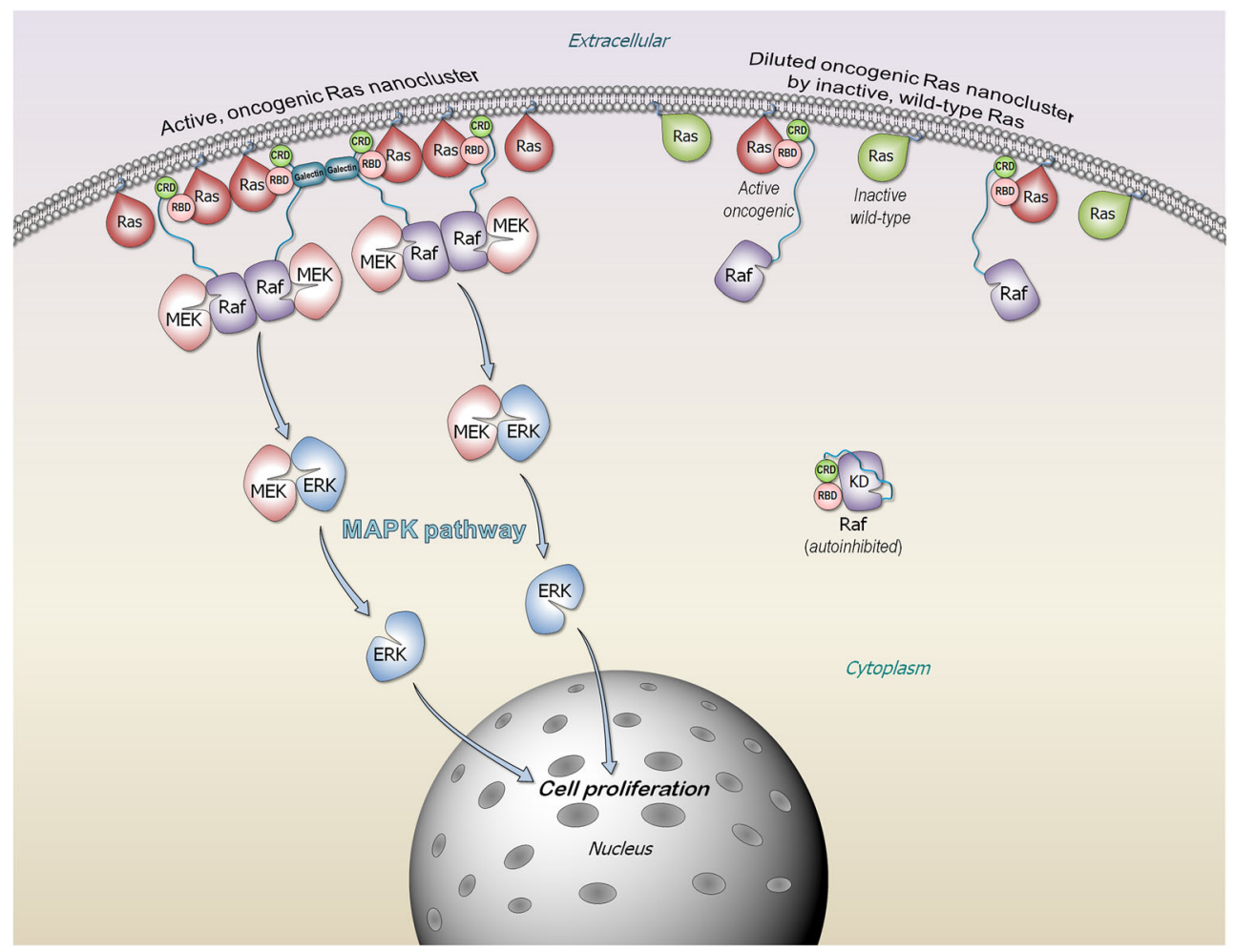

Fig. 3 Active, oncogenic Ras forms nanocluster at the membrane microdomain that can serve as a signaling platform. Ras nanocluster recruits Raf kinases to the membrane microdomain, promoting Raf kinase domain dimerization, activation, leading to signaling via the MAPK (Raf/MEK/ERK) phosphorylation pathway. Monomeric Raf is mainly autoinhibited in the cytosol. Ras releases the autoinhibition via the high-affinity interaction of Ras with Raf RBD. Inactive, wild-type Ras

dimers/nanoclusters. The varied chemistry of the HVRs, thus membrane preferences, favors distinct isoform nanoclusters. However, recently KRas4B nanoclusters were shown to be co-inhibited also by other isoforms and notably, by a subset of prenylated small GTPase family members, confirming the importance of dimer/co-cluster formation on cell membranes (Li et al. 2020b), in line with an earlier hypothesis making such prediction (Nussinov et al. 2020a).

A few years ago, wild-type HRas was observed to suppress HRas driven cancer (Spandidos et al. 1990). This was followed by the observation that wild-type KRas can inhibit lung cancer (Diaz et al. 2002) and that wild-type NRas can also suppress its mutant as potently as can KRas (Zhang et al. 2001). However, the data (To et al. 2013; Xu et al. 2013; Zhou et al. 2016) as to how would wild-type Ras suppress the oncogenicity of its mutant was not understood (Kong et al. 2016; Qiu et al. 2011; Staffas et al. 2015) despite its significant implications to Ras drug discovery (Zhou et al. 2016). Nanoclustering can resolve these apparent perplexing observations. In the absence of an external cue, wild-type Ras spends most of its life in the inactive state. "Diluting" the population of active, oncogenic Ras by the inactive wild type would lower the probability of spatially nearby active Ras dilutes the oncogenic Ras nanoclusters. The wild type normally exists in the cell in its GDP-bound form. Its intrinsic orientation on the membrane surface occludes its effector binding site, which is buried by the membrane, abrogating effector binding and suppressing Raf's activation. The cartoon was inspired by previous publication of MAPK suppression by Rap1 (Nussinov et al. 2020a)

molecules (Fig. 3), thus Raf dimerization, activation, and MAPK signaling. This effect is particularly large in cells with high KRas populations. Segregated nanoclustering also resolves the next question of why the wild-type state of one isoform type cannot suppress the oncogenic mutant of another (Matallanas et al. 2011; Xu et al. 2013). The apparent observed suppression of MAPK by Rap1A small GTPase, whose HVR resembles that of KRas4B, might also be explained along similar lines (Nussinov et al. 2020a).

\section{Ras isoforms display distinct favored interactions with Raf isoforms}

Ras/Raf/MEK/ERK is a major Ras signaling pathway involving protein kinases phosphorylation cascade (Lavoie and Therrien 2015). The sequences, structures and functions of Raf isoforms, A-Raf, B-Raf, and Raf-1 are mostly similar, and they share conserved regions (CRs); CR1, CR2, and CR3 (Shaw et al. 2014; Yaeger and Corcoran 2019). CR1 at the N-terminal, contains the RBD and the CRD. In active Raf, RBD interacts with Ras, and CRD binds to the membrane (Garcia-Gomez et al. 2018; Ghosh et al. 1994; Li et al. 2018b; Terrell and Morrison 2019; Travers et al. 2018) (Fig. 3). Inhibition of Raf can allosterically promote 
its paradoxical activation (Hatzivassiliou et al. 2010; Heidorn et al. 2010; Poulikakos et al. 2010) via heterodimeric interactions between the kinase domains of Raf isoforms (Jin et al. 2017; Pfister et al. 2008; Ritt et al. 2010). Dimerization of the kinase domains is required for full activation (Durrant and Morrison 2018; Hu et al. 2013; Lavoie et al. 2013; Rajakulendran et al. 2009). Under normal circumstances, B-Raf/Raf-1 heterodimers predominate (Freeman et al. 2013a).

Wild-type Raf is mostly in the "closed" autoinhibited state, where the CRD and RBD shield the kinase domain dimerization surface (Nussinov et al. 2020c), with the 14-3-3 proteins stabilizing this organization (Kondo et al. 2019; Park et al. 2019). Dephosphorylation of pSer365 in B-Raf (pSer259 in Raf-1) and release of RBD-CRD following a growth activation signal at the membrane relieve the autoinhibition. The high affinity binding of Raf's RBD to active Ras, coupled with pSer365 dephosphorylation which destabilizes the 14-3-3 interaction, shifts the Raf ensemble toward the open state (Zhang et al. 2021). This exposes the kinase domain dimerization surface enabling full activation (Fetics et al. 2015; Hatzivassiliou et al. 2010; Lu et al. 2016; Nussinov et al. 2015; Nussinov et al. 2019a). Cryo-EM structures (Kondo et al. 2019; Park et al. 2019) of the Raf kinase domain, RBD and CRD complexed with dimeric 14-3-3 validate the organization of the assembly and the paradoxical activation of Raf (Kondo et al. 2019).

Recent experiments probed the preferred interactions of Ras isoforms with Raf isoforms, by shuffling their $\mathrm{N}^{\prime}$ termini, which precede the RBD-CRD. The $\mathrm{N}^{\prime}$ termini vary significantly among the Raf isoforms (Fig. 4), whereas it is long (154 residues) and negatively charged in B-Raf, it is more neutral in Raf1 (55 residues) and A-Raf (18 residues). The experiments indicated that the $\mathrm{N}^{\prime}$ termini of Raf isoforms selectively bind the HVRs of Ras isoforms (Terrell et al. 2019). Replacing the Raf-1 terminus with B-Raf's reduced the HRas-Raf-1 binding but had no significant effect on KRas-Raf-1 interaction. As to Ras HVRs, Raf-1 has high affinity to all Ras isoforms. However, the lysine-rich polybasic region of KRas4B is important to BRaf selectivity due to its acidic $\mathrm{N}^{\prime}$ terminal region, resulting in the high-affinity KRas4B-B-Raf RBD interaction. Taken together, Raf-1 binds all Ras proteins; however, B-Raf favors $\mathrm{KRas} 4 \mathrm{~B}$, with the sequences responsible for these preferences residing in the N-terminal (for B-Raf) and the HVR at the Cterminal for KRas4B. Additionally, Raf-1 is important for the HRas interaction, with a fairly neutral HVR.

Even though these observations provide critical information, understanding them is marred by lack of structural data. This reflects the disordered nature of the $\mathrm{N}^{\prime}$ termini of Raf, especially the long B-Raf sequence. It is also unclear how the HVR concomitantly interacts with the membrane and Raf's termini. With structural data only for a fraction of the sequence, it is challenging to reliably model it.

\section{Isoform-specific localization}

Two-decades ago, Alan Wolfman raised the apt question of "How is it that similar proteins carry out different jobs in the cell?" (Wolfman 2001); his answer was "Location, Location, Location." He proceeded to survey literature reports and concluded that different functions may stem from the distinct subcellular localizations to which the isoforms are directed by their HVRs and patterns of prenylation. Nonetheless, even if Ras isoforms are localized to unique sets of cellular structures, the number of Ras isoform-specific interaction sites is limited, which underscores the importance of understanding why they apparently signal through distinct pathways. This may imply that a Ras isoform-dependent oncogenic phenotype necessitates (i) cooperation of additional cellular Ras proteins, (ii) a steady-state pool of their complexes, and (iii) availability of other proteins in the pathway in the cancer cell. Notably, Ras sublocalization at the plasma membrane is highly dynamic and can be altered depending on the GDP/GTP load or the palmitoylation status (AgudoIbanez et al. 2015). Electron microscopy indicated that HRas is mainly in the endoplasmic reticulum and Golgi of acinar cells; KRas in the membrane of ductal cells. Overall, Ras isoforms were observed to have distinct and separate cellular and subcellular distributions that likely persist even in transformed cells (Kocher et al. 2005).

\section{Differential Ras isoform expression}

\section{RAS isoforms are preferentially expressed in different cancer types}

The question of why the oncogenic $R A S$ isoforms are preferentially expressed in different cancer types has been baffling (Der 2014; Hobbs et al. 2016), and several hypotheses have been proposed to address it (e.g., Der 2014; Haigis et al. 2008; Lampson et al. 2013; Rauen 2013; Schuhmacher et al. 2008; more below). Among these, here we reason that the patterns of isoform expression in different cells can relate to the accessibility of the gene's regulatory regions. The density of chromatin in regulatory regions of highly expressed isoforms could be lower than of those with lower expression. Temporal expression profiles of different isoforms across developmental stages identified "isoform switching" of the predominant isoform ( $>60 \%$ of all isoforms of the given gene at the given stage) ( $\mathrm{Li}$ et al. 2020a). The chromatin density of specific genes differs between differentiated cells as compared to cells during embryogenesis. The local chromatin density can also vary among the differentiated cells, making the regulatory regions of some genes more accessible to the transcription machinery than others. This, along with the epigenetic features, control gene expression (Klemm et al. 2019), including in our case here 
Fig. 4 Sequences of the $\mathrm{N}^{\prime}$ termini and RBD-CRD of Raf isoforms, B-Raf and Raf-1 (upper panel). In the sequences, basic residues (positively charged) are colored in blue, acidic residues (negatively charged) are colored in red, hydrophobic residues are colored in black, and polar and glycine residues are colored in green. The B-Raf $\mathrm{N}^{\prime}$ terminus is longer (154 residues) than that of Raf-1 (54 residues). Underlines denote the RBD and CRD residues. A collection of domain structures for Raf N-terminal region are shown in the lower panel. Crystal structures of B-Rafspecific (BRS) domain (PDB: 5VR3) and B-Raf RBD (PDB: 3NY5). Solution structures of Raf-1 CRD (PDB: 1FAR) and kinase suppressor of Ras 1 (KSR1) C2 domain (PDB: $1 \mathrm{KBE})$. In the cartoon, the same colors are used as in the sequence, except the hydrophobic residues colored in white. In Raf-1 CRD, sticks highlight the Cys152, Cys155, His 173, and Cys176 residues coordinated with the first $\mathrm{Zn}^{2+}$, and the His139, Cys165, Cys168, and Cys184 residues coordinated with the second $\mathrm{Zn}^{2+}$. Similarly, for KSR1 C2 domain His334, Cys359, Cys362, and Cys 377 coordinated with the first $\mathrm{Zn}^{2+}$, and Cys346, Cys349,

His 367 , and Cys 370 coordinated with the second $\mathrm{Zn}^{2+}$

\begin{tabular}{|c|c|c|c|c|c|}
\hline \multirow{2}{*}{ B-Raf } & 10 & 20 & 30 & 40 & 50 \\
\hline & MAALSGGGGG & GAEPGQALFN & GDMEPEAGAG & AGAAASSAAD & PAIPEEVWNI \\
\hline \multirow[b]{2}{*}{ B-Raf } & 60 & 70 & 80 & 90 & 100 \\
\hline & KQMIKLTQEH & IEALLDKFGG & EHNPPSIYLE & AYEEYTSKLD & ALQQREQQLL \\
\hline \multirow{4}{*}{$\begin{array}{l}\text { B-Raf } \\
\text { Raf-1 }\end{array}$} & 110 & 120 & 130 & 140 & 150 \\
\hline & ESLGNGTDFS & VSSSASMDTV & TSSSSSSLSV & LPSSLSVFQN & PTDVARSNPK \\
\hline & MEHIQGAWKT & ISNGFGFKDA & VFDGSSCISP & TIVQQFGYQR & RASDDGKLTD \\
\hline & 10 & 20 & 30 & 40 & 50 \\
\hline \multirow{4}{*}{$\begin{array}{l}\text { B-Raf } \\
\text { Raf-1 }\end{array}$} & 159 & 169 & 179 & 189 & 199 \\
\hline & . SPQKPIVRV & FLPNKQRTVV & PARCGVTVRD & SLKKALMMRG & LIPECCAVYR \\
\hline & PSKTSNTIRV & FLPNKQRTVV & NVRNGMSLHD & CIMKALKVRG & LQPECCAVFR \\
\hline & 60 & 70 & 80 & 90 & $\overline{100}$ \\
\hline \multirow{4}{*}{$\begin{array}{l}\text { B-Raf } \\
\text { Raf-1 }\end{array}$} & 206 & 216 & 226 & 236 & 246 \\
\hline & I. . . QDGEKK & PIGWDTDISW & LTGEELHVEV & LENVPLTTHN & FVRKTFFTLA \\
\hline & $\overline{\mathrm{L}} \mathrm{L} H \mathrm{HKGKKA}$ & RLDWNTDAAS & LIGEELOVDF & IDHVPLTTHN & FARKTFLKLA \\
\hline & 110 & 120 & 130 & 140 & 150 \\
\hline \multirow{4}{*}{$\begin{array}{l}\text { B-Raf } \\
\text { Raf-1 }\end{array}$} & 256 & 266 & 276 & 286 & \\
\hline & $\underline{F}$ CDFCRKLLF & QGFRCQTCGY & KFHQRCSTEV & PLMCVNYDQL & \\
\hline & FCDICQKFLL & NGFRCQTCGY & KFHEHCSTKV & PTMCVDWSNI & \\
\hline & 160 & 170 & 180 & 190 & \\
\hline
\end{tabular}

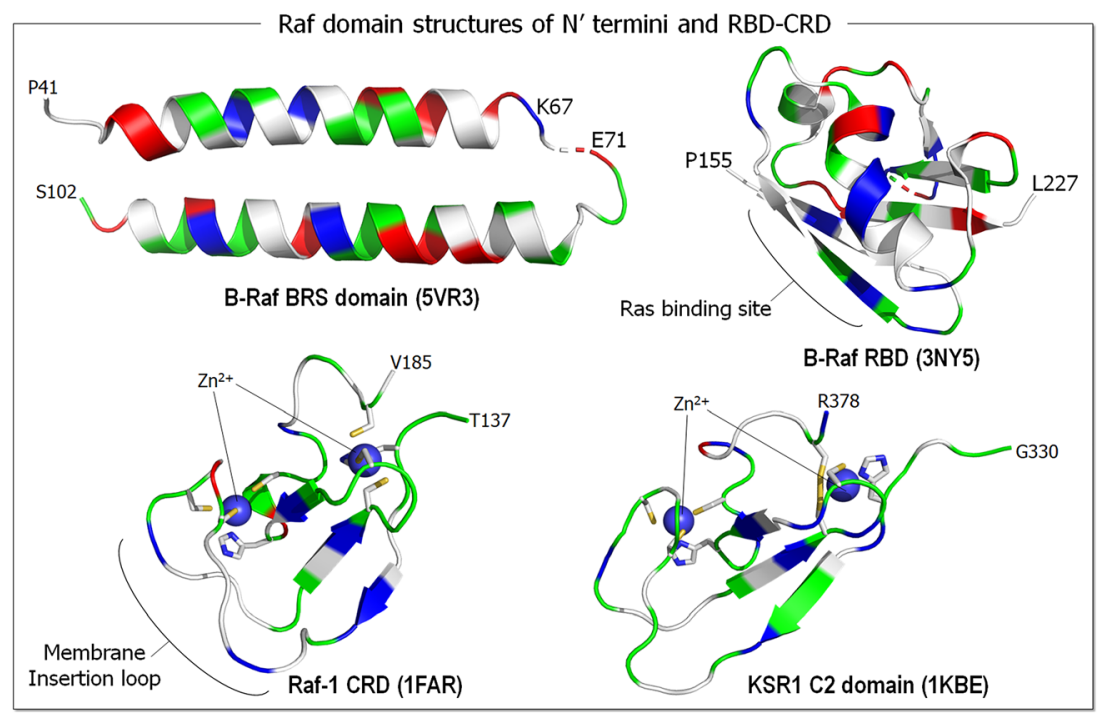

wild-type and mutant Ras isoforms (Nussinov et al. 2021), thus signaling.

This picture becomes even more complex when Raf's expression and mutational patterns are considered (Desideri et al. 2015). Mutations in B-Raf, but not in A-Raf and Raf1 , are common in human cancers, with Raf-1 mutations at under 1\% (Imielinski et al. 2014). Mutations were observed in pancreatic and lung adenocarcinoma and colorectal cancer, where KRas4B is commonly involved. It is overexpressed in bladder cancer, hepatocellular carcinoma, squamous cell carcinoma, and lung adenocarcinoma (Maurer et al. 2011) and is MEK independent (Blasco et al. 2011; Karreth et al. 2011).

\section{Quantitative data on isoform-specific expression are limited}

Isoform-specific expression has been probed, as well as its relation to signaling (Newlaczyl 2016) and prognosis (Yang and Kim 2018). KRas4B was confirmed as the most highly expressed isoform and KRas4A as the most dynamically regulated. Quantification of Ras isoform expression during development by real-time polymerase chain reaction (PCR) in mouse tissues indicated a relative contribution of KRas4B > $>$ NRas $\geq$ KRas4A $>$ HRas to total Ras expression (Newlaczyl et al. 2017), where KRas4B is about 60-99\% of all Ras transcripts. Recent data have also suggested that spliced variants are translationally significant (Raso 2020). This may reflect the dependence of multiple factors, including cell type, tissue heterogeneity, timing, sparsity of data, defining flexible statistical frameworks for complex differential patterns in gene expression, assigning a reference, errors and missing data, and from our standpoint as we discuss here, key factors are measuring chromatin accessibility (Buenrostro et al. 2015; Cusanovich et al. 2015) and epigenetics, such as DNA methylation (Karemaker and Vermeulen 2018) and more (Lahnemann et al. 2020). 
HRas, KRas, and NRas have specific context-dependent functions (Hobbs et al. 2016; Nussinov et al. 2018a; Nussinov et al. 2020b), and mutations (Li et al. 2018a; Munoz-Maldonado et al. 2019). They also display cancer type specific incidence: KRas in pancreatic, lung, and colorectal carcinomas, NRas in cutaneous melanoma (Cox et al. 2014), and HRas in head and neck and bladder squamous cell carcinomas. Several theories have been put forward to explain the cell (tissue)-specificity. Among them (Der 2014), (i) isoform specificity reflects the level of expression. Yet, the significantly higher incidence of KRAS mutations as compared to NRAS (Haigis et al. 2008) and HRAS (Schuhmacher et al. 2008) in colorectal carcinoma was offered as questioning this explanation. Another explanation (ii) relates to possible differential potencies in promoting cancers across tissues (Haigis et al. 2008; Russo et al. 2014). (iii) An alternative explanation offered differential DNA repair as a consequence of Ras isoform-specific activating mutations (Ise et al. 2000). This suggested that KRAS regulatory elements are responsible for tissue specificity, rather than the Ras protein (Chin et al. 1997; To et al. 2008). Still other explanations suggested (iv) that isoform translational efficiency encoded by codon usage could be the origin of the isoform specificity (Lampson et al. 2013) and finally, as analysis of The Cancer Genome Atlas indicated (v), tumor $R A S$ gene expression levels are influenced by the mutational status of $R A S$ genes and of upstream and downstream Ras pathway genes (Stephens et al. 2017).

Furthering the differential potencies of mutants in promoting cancers across tissues (Haigis et al. 2008; Russo et al. 2014), we propose a role for chromatin accessibility (Fig. 5). The genome of all cells is identical. However, not all genes are equally expressed during the developmental lineage and across tissue microenvironments. One major reason is the status of the chromatin density in gene regulatory regions. Regulatory regions can be buried in compact dense chromatin or be in low-density regions. In low density regions, the local chromatin conformation is controlled by nucleosome dynamics. These regions can become available to the transcription machinery upon a relatively minor conformational change (Nussinov et al. 2020b). There is a continuum of accessibility across the genome (Klemm et al. 2019), stretching from genes expressed only in embryonic cells, to those in differentiated cells, as in the case of Ras isoforms. Accessibility reflects the cell's epigenetic landscape (Haigis et al. 2019; Sack et al. 2018) and relates to the density of proteins interacting directly (mostly histones) or indirectly with the DNA and their fractional residence times. Accessibility is a major factor determining gene expression, thus protein availability and consequently, pathways that consist of interactions of these proteins. Protein availability differs among tissues: protein levels in pancreatic cells where KRas expression is abundant may differ from those in skin cells, where NRas is (Nussinov et al. 2020b). Taken together, KRas and NRas can be differentially expressed in specific cell types because their chromatin accessibility status differ (Brubaker et al. 2019). This could clarify why the heightened abundance of the same active mutant, e.g., KRas ${ }^{\mathrm{G} 12 \mathrm{D}}$, would differ in pancreatic cancer and melanoma skin cancer. On the other hand, the differential outcome of $\mathrm{NRas}^{\mathrm{Q} 61 \mathrm{R}}$ versus NRas ${ }^{\mathrm{G} 12 \mathrm{D}}$ in melanoma may stem from the differential mutation strengths, which depends on the activation mechanisms (Burd et al. 2014). Exploring the respective mechanisms would be of interest and could aid in development of isoform- and mutantspecific inhibitors.

\section{Chromatin accessibility and genome organization are cell-type and cell-state specific}

To fit into the limited nuclei space, act in regulation and guard genome integrity, chromatin is compacted. Compactness has been assessed by several methods, including a quantitative fluctuation-based assay (Hinde et al. 2012) and FRET; however, the low resolution does not permit correlation of the in vivo signals with specific higher order chromatin organization (Lleres et al. 2009). Quantitative super-resolution microscopy assay (Dultz et al. 2018) and algorithms for the quantification of chromatin condensation from microscopic data have been developed, but to date their applications have been limited (Sosnik et al. 2017). Chromatin accessibility reflects changes in the local density, or compaction (Magana-Acosta and Valadez-Graham 2020). Dynamic changes in chromatin landscapes are associated with cell differentiation during embryogenesis and dedifferentiation in pluripotent stem cell (iPSC) in cancers. Among the factors defining chromatin states are the composition and post-translational modifications (PTMs) of the nucleosomes, concentration and interaction of transcription factors, and chromatin remodelers (Klemm et al. 2019). The mechanisms controlling accessible chromatin regions include competition between transcription factors and histones, chromatin remodeling in cis through proximal linker histone displacement, and in trans through accessible, distal regulatory elements, binding of the pioneer transcription factors to nucleosomal DNA and more (Klemm et al. 2019). Landscapes vary in different tissues and cell types.

Most chromatin conformation capture experiments focused on intrachromosomal interactions. Recent observations reveal that the patterns of interchromosomal interactions are tissuespecific, differing between the heart and liver (Chapski et al. 2018). The experiments (Nothjunge et al. 2017; Rosa-Garrido et al. 2017) show preferential localization of genes in 3D in the nuclei of the organs in which the genes are transcribed. Comparisons of liver and cardiac chromatin structures identify widespread differences in compartmentalization, with these not fully correlating with the organ transcriptional states. Localization of genes within organ-specific chromatin scaffolds relate to cell type but can reflect stress conditions as well. Genome structures indicate that the promoter to transposable element loops differ between the organs, pointing to cell type 


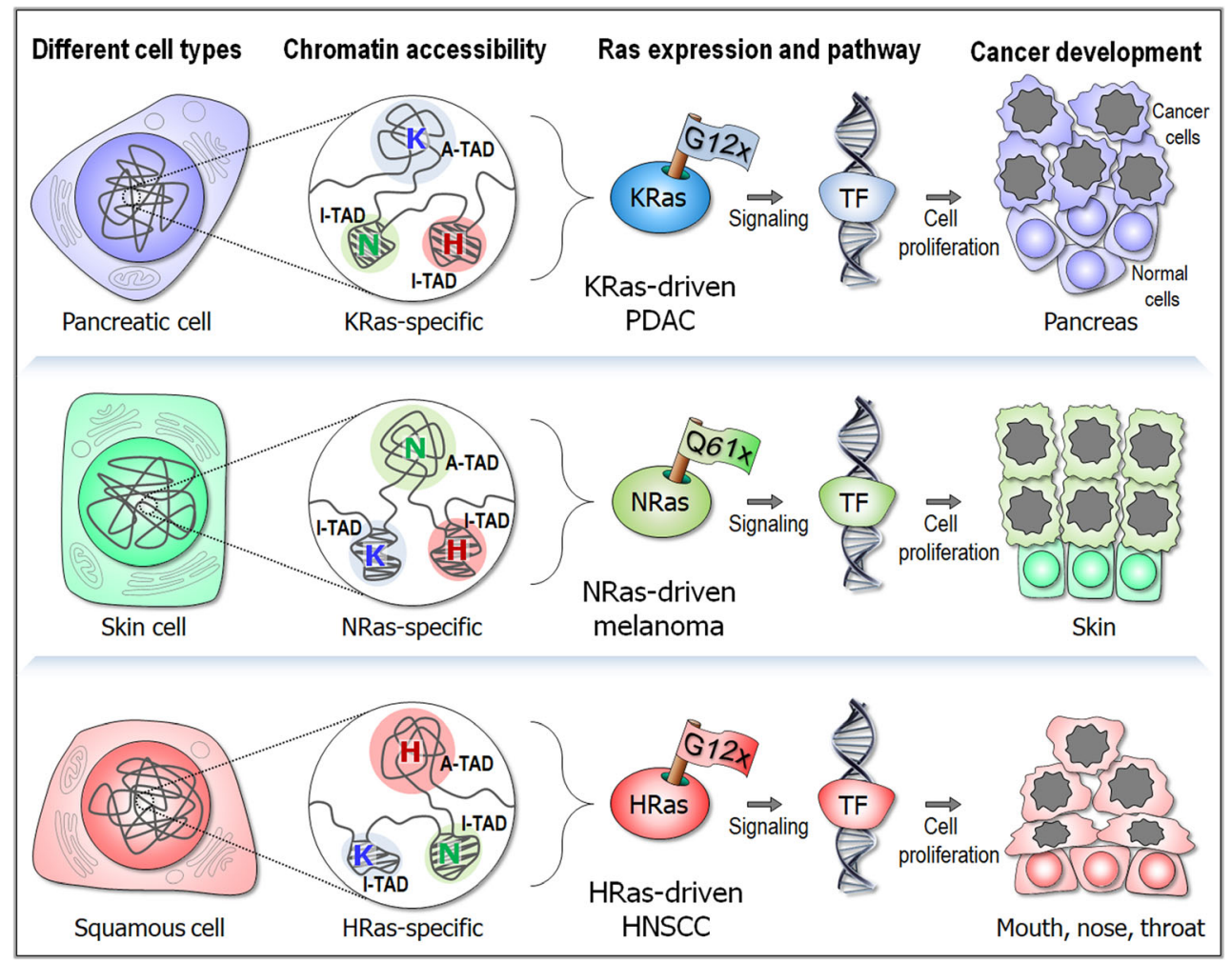

Fig. 5 Dynamic chromatin accessibility and cell-specific signaling pathways of Ras isoforms. KRas G12x mutations dominantly drive pancreatic ductal adenocarcinoma (PDAC), while NRas Q61x mutations are often found in melanoma. HRas mutations frequently occur in head and neck squamous cell carcinoma (HNSCC). Ras isoform expression in different cell types can relate to chromatin accessibility states of specific topologically associating domains (TAD) (Szabo et al. 2019). In the cell nucleus, the disordered chain represents the chromatin, a chromosome in

specific organization of the epigenome. Interchromosomal interactions were enriched in genes associated with the function of that cell type, localizing nearby (Cremer and Cremer 2001) in "transcription factories" (Papantonis and Cook 2013). In the heart, $66.7 \%$ of cardiac-specific genes are in the center of one compartment (marked compartment A), while $66.1 \%$ of liver-specific genes are toward the periphery in compartment $\mathrm{B}$. The locations of the Ras isoforms on the human chromosomes also differ (Pellicer 2011; Rajasekharan and Raman 2013): HRAS gene is localized to the short arm (p) of chromosome 11 at position 5, the KRAS gene is located on the $\mathrm{p}$ arm of chromosome 12 at position 12.1, and the NRAS gene is on chromosome 1 at position 13.2. Even though these are positions along the linear chromosome sequence organization, and to date data about their 3D locations are unavailable, the distinct locations of isoforms suggest distinct organization and expression patterns.

Advancements in super-resolution imaging (e.g., Nir et al. 2018) coupled with measurements of mRNA expression in distinct cell types and states can test whether the patterns of Ras isoform expression are associated with chromatin accessibility (Nussinov et al. 2021; Nussinov et al. 2020b). interphase. Examples of different chromatin accessibility for $R A S$ isoform-specific TAD conformations are highlighted in the circles. In the highlighted chromatin, A-TAD and I-TAD denote active and inactive TADs, respectively. $\mathrm{K}, \mathrm{N}$, and $\mathrm{H}$ indicate isoform-specific genes in the chromatin. Oncogenic Ras stimulates cancer signaling toward the transcription factor (TF) bound DNA that regulates the transcription of genes to cell proliferation. The phenotype of the production is cancer development

\section{Ras isoforms, their functions, and cell signaling}

\section{Differential isoform signaling}

A key question is how a specific pathway can be selected when the affinities of the effectors for each Ras isoform do not show appreciable differences (Sieburth et al. 1998; Wolfman 2001). That is, how can highly similar proteins carry out different actions in the cell? Possible explanations to this conundrum include (i) cell type-specific expression levels of the Ras isoforms, and of all nodes (proteins) in the respective pathway. For the signal to propagate, the levels of expression of these nodes need to be sufficiently high. (ii) Observations for over two decades (reviewed in, e.g., Castellano and Santos 2011; Garcia-Ibanez et al. 2020; Hobbs et al. 2016; Kattan and Hancock 2020; Mo et al. 2018) suggest that isoform functions may emerge from the subcellular localization favored by their HVRs (Wolfman 2001) (Fig. 1). Isoform-specific functions of Ras can be at least partly explained by localization (Fig. 2). For example, NRas and HRas, but not KRas, are expressed on the Golgi as well as the plasma membranes and it was recently 
reported that this localization inhibits malignant transformation (Casar et al. 2018). KRas4A but not KRas4B directly regulates hexokinase 1 by virtue of its unique localization on the outer mitochondrial membrane driven by depalmitoylation (Amendola et al. 2019). Compartmentalized signaling based on HVR-driven subcellular localization has been established in model organisms (Onken et al. 2006) and finally, a stark example of differential signaling from distinct subcellular locations is in T cell thymic selection (Daniels et al. 2006). (iii) Mutational potency is often isoform tissue specific (MunozMaldonado et al. 2019). The strong KRas $4 \mathrm{~B}^{\mathrm{G} 12 \mathrm{D}}$ driver interferes with GTP hydrolysis. It occurs broadly, but especially in pancreatic cancers. In contrast, the less frequent, weaker KRas4B ${ }^{\mathrm{A} 146 \mathrm{~T}}$ drives cancer by promoting GDP by GTP exchange. It has been observed in colorectal and hematopoietic cancers, but not in pancreatic adenocarcinomas where it is not sufficiently powerful for cell transformation (Bera et al. 2019; Poulin et al. 2019).

\section{Major considerations in signaling outputs in distinct tumors}

Thus, taken together, signaling outputs in distinct tumors reflect several major components. These include first, the expression levels which depend on chromatin accessibility in the respective cell type at that time window (Fig. 5). The local density of chromatin at the regulatory region of the gene and nearby in cis has to be low to permit binding of the transcription machinery and high expression rates. Indeed, even very high expression level on its own can promote cancer. Second, expression of other proteins in the respective pathway should not be low for the signal to propagate. Third, the mutations should be potent. When considering different mutations in the same cell/tumor, heightened abundance of activated Ras species depends on the expression level of that gene and the potency of the mutation. The NRas ${ }^{\text {Q61R }}$ mutations versus KRas ${ }^{\text {G12D }}$ in melanoma cell line provide an example (Burd et al. 2014). As clinical data have shown, the number of activated KRas ${ }^{\mathrm{G} 12 \mathrm{D}}$ molecules in pancreatic cancer is extremely high.

\section{Calmodulin interacts selectively with oncogenic KRas4B}

With a negatively charged linker and hydrophobic pockets, calmodulin $(\mathrm{CaM})$ interacts with KRas4B (Abraham et al. 2009; Chavan et al. 2013; Jang et al. 2017; Jang et al. 2019; Villalonga et al. 2001; Wu et al. 2011), and likely also with KRas4A, but not with the HRas and NRas isoforms (Nussinov et al. 2016). The high affinity charge-charge interaction coupled with the farnesyl nestling in CaM's hydrophobic pocket, shifts the ensembles toward this energetically favored state, extracting KRas molecules from the membrane (Fivaz and Meyer 2005; Sidhu et al. 2003; Sperlich et al. 2016).
While CaM's interaction appears KRas4B GTP-dependent (Abraham et al. 2009; Chavan et al. 2013; Villalonga et al. 2001; Wu et al. 2011), it can also involve the GDP-bound state (Agamasu et al. 2019; Fivaz and Meyer 2005; Sidhu et al. 2003; Sperlich et al. 2016). This can be understood in terms of the availability of the HVR for the interaction (Jang et al. 2019). In solution, the HVR in the GDP-bound state interacts with the catalytic domain, populating an autoinhibited state (Chavan et al. 2015a; Lu et al. 2015). However, the interaction is unstable which is why it has not been captured in the crystal, suggesting a minor GDP-bound KRas4B population with the HVR available for CaM interaction (Jang et al. 2016a; Nussinov et al. 2018b). At the membrane, likely being sandwiched between the catalytic domain and the bilayer surface the autoinhibited state can persist (Jang et al. 2016a).

CaM's binding to mutant KRas4B is vastly important to understand. Two possible reasons have been advanced to explain its role: (i) $\mathrm{CaM}-\mathrm{KRas} 4 \mathrm{~B}$-specific binding reduces the number of available free $\mathrm{CaM}$ molecules for $\mathrm{Ca}^{2+}$-dependent protein kinase II activation (Wang et al. 2015); (ii) phosphorylated CaM and mutant KRas4B bind PI3K $\alpha$ and activate it (Joyal et al. 1997; Wang et al. 2018; Zhang et al. 2017; Zhang et al. 2018). Together, mutant KRas4B and CaM can stimulate the PI3K $\alpha /$ AKT pathway even in its absence of an incoming receptor tyrosine kinase growth signal. CaM's fundamental significance in KRas-driven adenocarcinoma made it a prime drug discovery target.

\section{Conclusions}

Even though there are some sequence differences in the catalytic domains, the distinction among Ras isoforms rests mainly in their HVR membrane-binding segments (Fig. 1). This distinction underscores the significance of the attachment to membrane domains in determining isoform functions, cellular sublocalization and shuttling vehicles to get them there (Fig. 2). The chemical uniqueness of the HVRs stemming from the variable amino acid sequences and the combination of prenyl modifications, with the consequent separation into mostly homogeneous nanoclusters, emphasizes their specific roles under normal conditions and the resulting mutational distributions observed in cancer. As recent work elegantly demonstrated (Terrell et al. 2019), Ras isoforms interact differentially with Raf isoforms, with Raf-1 binding all mutant Ras proteins with high affinity, whereas B-Raf exhibiting a strong preference for mutant KRas. It is thus quite likely that Ras isoforms also differentially interact with other Ras effectors, such as PI3K $\alpha$ (Thevathasan et al. 2013). Even though differential KRas and HRas regulation by galectin isoforms was also observed (Elad-Sfadia et al. 2004; Shalom-Feuerstein et al. 2005), more recently the interaction was proposed to be mediated via Raf's RBD (Blazevits et al. 2016), thereby 
cooperatively scaffold Ras nanoclusters, which would increase dimerization of Raf's kinase domains and activation.

All proteins are encoded and can be expressed by all cells (Kosti et al. 2016). However, genes are preferentially expressed in tissues (Farahbod and Pavlidis 2019; Honore 2020): proteins expressed in pancreatic cells may not be equally expressed in lung cells. This holds for isoforms of Ras and other proteins, including receptor tyrosine kinases and lipid kinases. It is the rule - not an exception, and it can be at least partly understood in terms of chromatin organization and incoming signaling cues (Fig. 5) and mRNA levels (Lorch and Kornberg 2017; Rolicka et al. 2020). Genes are expressed when they can be sufficiently exposed for the transcription machinery to trigger remodeling of the chromatin conformation, and they are less so when they are persistently buried in dense chromatin (Magana-Acosta and Valadez-Graham 2020). Chromatin remodeling takes place in cancer (Arildsen et al. 2017; Lafon-Hughes et al. 2008; Morgan and Shilatifard 2015). Cell type and cell state epigenetic organizations are key factors determining gene expression status, and the expressed proteins are wired in the cellular proteinprotein interaction network. Super high-resolution electron microscopy and computational prediction methodologies are rapidly advancing, and they are being applied to cell-specific cancer genomes. This raises hope that $R A S$ isoform-specific gene scale topologically associating domains (TAD) will be identified not only in specific tissues (Szabo et al. 2019), but also at different cell-transformation states. Such detailed maps could help forecast gene expression and alternative signaling pathways in drug resistance (Nussinov et al. 2021; Nussinov et al. 2020b). The anchorage of Ras isoforms in the membrane and their nanoclustering have been studied extensively, including their detailed interactions, sizes, and preferred membrane environments, chemistry and geometry (Lee et al. 2019). However, the challenge of their epigenetics and its linkage to rewired networks in distinct cell states and types is still waiting to be unraveled. The landscape of accessibility changes dynamically in response to external and developmental cues (Klemm et al. 2019). But its tissue-specific footprints may help in deciphering the impending pathways in drug resistance.

To date, pharmacology has successfully targeted KRas4B ${ }^{\mathrm{G} 12 \mathrm{C}}$ (Zeng et al. 2020; Zhang et al. 2020). Ras isoform-specific pharmacology at the membrane has been deliberated. However, considering membrane fluidity, the common presence of phosphatidylserine, and the non-uniqueness of the PTMs, toxicity is a challenge. Whereas pharmacological innovations are compelling, reliably forecasting future developments is formidable, making the harnessing of the signaling pathways appear more tractable venues.

Acknowledgements This project has been funded in whole or in part with federal funds from the National Cancer Institute, National Institutes of Health, under contract HHSN26120080001E. The content of this publication does not necessarily reflect the views or policies of the Department of Health and Human Services, nor does mention of trade names, commercial products, or organizations imply endorsement by the U.S. Government. This Research was supported [in part] by the Intramural Research Program of the NIH, National Cancer Institute, Center for Cancer Research.

Funding This project has been funded in whole or in part with federal funds from the National Cancer Institute, National Institutes of Health, under contract HHSN26120080001E. This Research was supported (in part) by the Intramural Research Program of the NIH, National Cancer Institute, Center for Cancer Research.

\section{Declarations}

Disclaimer The content of this publication does not necessarily reflect the views or policies of the Department of Health and Human Services, nor does mention of trade names, commercial products, or organizations imply endorsement by the U.S. Government.

Open Access This article is licensed under a Creative Commons Attribution 4.0 International License, which permits use, sharing, adaptation, distribution and reproduction in any medium or format, as long as you give appropriate credit to the original author(s) and the source, provide a link to the Creative Commons licence, and indicate if changes were made. The images or other third party material in this article are included in the article's Creative Commons licence, unless indicated otherwise in a credit line to the material. If material is not included in the article's Creative Commons licence and your intended use is not permitted by statutory regulation or exceeds the permitted use, you will need to obtain permission directly from the copyright holder. To view a copy of this licence, visit http://creativecommons.org/licenses/by/4.0/.

\section{References}

Abe T, Umeki I, Kanno SI, Inoue SI, Niihori T, Aoki Y (2020) LZTR1 facilitates polyubiquitination and degradation of RAS-GTPases. Cell Death Differ 27:1023-1035. https://doi.org/10.1038/s41418019-0395-5

Abraham SJ, Nolet RP, Calvert RJ, Anderson LM, Gaponenko V (2009) The hypervariable region of K-Ras4B is responsible for its specific interactions with calmodulin. Biochemistry 48:7575-7583. https:// doi.org/10.1021/bi900769j

Agamasu C, Ghirlando R, Taylor T, Messing S, Tran TH, Bindu L, Tonelli M, Nissley DV, McCormick F, Stephen AG (2019) KRAS prenylation is required for bivalent binding with calmodulin in a nucleotide-independent manner. Biophys J 116:1049-1063. https://doi.org/10.1016/j.bpj.2019.02.004

Agudo-Ibanez L, Herrero A, Barbacid M, Crespo P (2015) H-ras distribution and signaling in plasma membrane microdomains are regulated by acylation and deacylation events. Mol Cell Biol 35:18981914. https://doi.org/10.1128/MCB.01398-14

Ahearn I, Zhou M, Philips MR (2018) Posttranslational modifications of RAS proteins. Cold Spring Harb Perspect Med 8:a031484. https:// doi.org/10.1101/cshperspect.a031484

Amendola CR, Mahaffey JP, Parker SJ, Ahearn IM, Chen WC, Zhou M, Court H, Shi J, Mendoza SL, Morten MJ, Rothenberg E, Gottlieb E, Wadghiri YZ, Possemato R, Hubbard SR, Balmain A, Kimmelman AC, Philips MR (2019) KRAS4A directly regulates hexokinase 1. Nature 576:482-486. https://doi.org/10.1038/s41586-019-1832-9

Arildsen NS, Jonsson JM, Bartuma K, Ebbesson A, Westbom-Fremer S, Masback A, Malander S, Nilbert M, Hedenfalk IA (2017) 
Involvement of chromatin remodeling genes and the Rho GTPases RhoB and CDC42 in ovarian clear cell carcinoma. Front Oncol 7: 109. https://doi.org/10.3389/fonc.2017.00109

Ashwin SS, Nozaki T, Maeshima K, Sasai M (2019) Organization of fast and slow chromatin revealed by single-nucleosome dynamics. Proc Natl Acad Sci U S A 116:19939-19944. https://doi.org/10.1073/ pnas. 1907342116

Baker R, Lewis SM, Sasaki AT, Wilkerson EM, Locasale JW, Cantley LC, Kuhlman B, Dohlman HG, Campbell SL (2013a) Site-specific monoubiquitination activates Ras by impeding GTPase-activating protein function. Nat Struct Mol Biol 20:46-52. https://doi.org/10. $1038 / \mathrm{nsmb} .2430$

Baker R, Wilkerson EM, Sumita K, Isom DG, Sasaki AT, Dohlman HG, Campbell SL (2013b) Differences in the regulation of K-Ras and HRas isoforms by monoubiquitination. J Biol Chem 288:3685636862. https://doi.org/10.1074/jbc.C113.525691

Bandaru P, Kondo Y, Kuriyan J (2019) The interdependent activation of son-of-sevenless and Ras. Cold Spring Harb Perspect Med 9: a031534. https://doi.org/10.1101/cshperspect.a031534

Banerjee A, Jang H, Nussinov R, Gaponenko V (2016) The disordered hypervariable region and the folded catalytic domain of oncogenic K-Ras4B partner in phospholipid binding. Curr Opin Struct Biol 36: 10-17. https://doi.org/10.1016/j.sbi.2015.11.010

Barth R, Bystricky K, Shaban HA (2020) Coupling chromatin structure and dynamics by live super-resolution imaging. Sci Adv 6: eaaz2196. https://doi.org/10.1126/sciadv.aaz2196

Bera AK, Lu J, Wales TE, Gondi S, Gurbani D, Nelson A, Engen JR, Westover KD (2019) Structural basis of the atypical activation mechanism of KRAS(V14I). J Biol Chem 294:13964-13972. https://doi.org/10.1074/jbc.RA119.009131

Bivona TG, Quatela SE, Bodemann BO, Ahearn IM, Soskis MJ, Mor A, Miura J, Wiener HH, Wright L, Saba SG, Yim D, Fein A, Perez de Castro I, Li C, Thompson CB, Cox AD, Philips MR (2006) PKC regulates a farnesyl-electrostatic switch on K-Ras that promotes its association with Bcl-XL on mitochondria and induces apoptosis. Mol Cell 21:481-493. https://doi.org/10.1016/j.molcel.2006.01.012

Blasco RB, Francoz S, Santamaria D, Canamero M, Dubus P, Charron J, Baccarini M, Barbacid M (2011) c-Raf, but not B-Raf, is essential for development of K-Ras oncogene-driven non-small cell lung carcinoma. Cancer Cell 19:652-663. https://doi.org/10.1016/j.ccr. 2011.04.002

Blazevits O, Mideksa YG, Solman M, Ligabue A, Ariotti N, Nakhaeizadeh H, Fansa EK, Papageorgiou AC, Wittinghofer A, Ahmadian MR, Abankwa D (2016) Galectin-1 dimers can scaffold Raf-effectors to increase H-ras nanoclustering. Sci Rep 6:24165. https://doi.org/10.1038/srep24165

Boriack-Sjodin PA, Margarit SM, Bar-Sagi D, Kuriyan J (1998) The structural basis of the activation of Ras by Sos. Nature 394:337343. https://doi.org/10.1038/28548

Brubaker DK, Paulo JA, Sheth S, Poulin EJ, Popow O, Joughin BA, Strasser SD, Starchenko A, Gygi SP, Lauffenburger DA, Haigis KM (2019) Proteogenomic network analysis of context-specific KRAS signaling in mouse-to-human cross-species translation. Cell Syst 9(258-270):e256. https://doi.org/10.1016/j.cels.2019.07.006

Buenrostro JD, Wu B, Litzenburger UM, Ruff D, Gonzales ML, Snyder MP, Chang HY, Greenleaf WJ (2015) Single-cell chromatin accessibility reveals principles of regulatory variation. Nature 523:486490. https://doi.org/10.1038/nature14590

Burd CE, Liu W, Huynh MV, Waqas MA, Gillahan JE, Clark KS, Fu K, Martin BL, Jeck WR, Souroullas GP, Darr DB, Zedek DC, Miley MJ, Baguley BC, Campbell SL, Sharpless NE (2014) Mutationspecific RAS oncogenicity explains NRAS codon 61 selection in melanoma. Cancer Discov 4:1418-1429. https://doi.org/10.1158/ 2159-8290.CD-14-0729

Casar B, Badrock AP, Jimenez I, Arozarena I, Colon-Bolea P, LorenzoMartin LF, Barinaga-Rementeria I, Barriuso J, Cappitelli V,
Donoghue DJ, Bustelo XR, Hurlstone A, Crespo P (2018) RAS at the Golgi antagonizes malignant transformation through PTPRkappa-mediated inhibition of ERK activation. Nat Commun 9:3595. https://doi.org/10.1038/s41467-018-05941-8

Castellano E, Santos E (2011) Functional specificity of ras isoforms: so similar but so different. Genes Cancer 2:216-231. https://doi.org/10. $1177 / 1947601911408081$

Chakrabarti M, Jang H, Nussinov R (2016) Comparison of the conformations of KRAS isoforms, K-Ras4A and K-Ras4B, points to similarities and significant differences. J Phys Chem B 120:667-679. https://doi.org/10.1021/acs.jpcb.5b11110

Chapski DJ, Rosa-Garrido M, Hua N, Alber F, Vondriska TM (2018) Spatial principles of chromatin architecture associated with organspecific gene regulation. Front Cardiovasc Med 5:186. https://doi. org/10.3389/fcvm.2018.00186

Chavan TS, Abraham S, Gaponenko V (2013) Application of reductive (1)(3)C-methylation of lysines to enhance the sensitivity of conventional NMR methods. Molecules 18:7103-7119. https://doi.org/10. 3390/molecules 18067103

Chavan TS, Jang H, Khavrutskii L, Abraham SJ, Banerjee A, Freed BC, Johannessen L, Tarasov SG, Gaponenko V, Nussinov R, Tarasova NI (2015a) High-affinity interaction of the K-Ras4B hypervariable region with the Ras active site. Biophys J 109:2602-2613. https:// doi.org/10.1016/j.bpj.2015.09.034

Chavan TS, Muratcioglu S, Marszalek R, Jang H, Keskin O, Gursoy A, Nussinov R, Gaponenko V (2015b) Plasma membrane regulates Ras signaling networks. Cell Logist 5:e1136374. https://doi.org/ 10.1080/21592799.2015.1136374

Cherfils J, Zeghouf M (2013) Regulation of small GTPases by GEFs, GAPs, and GDIs. Physiol Rev 93:269-309. https://doi.org/10.1152/ physrev.00003.2012

Chin L, Pomerantz J, Polsky D, Jacobson M, Cohen C, Cordon-Cardo C, Horner JW 2nd, DePinho RA (1997) Cooperative effects of INK4a and ras in melanoma susceptibility in vivo. Genes Dev 11:28222834. https://doi.org/10.1101/gad.11.21.2822

Cox AD, Fesik SW, Kimmelman AC, Luo J, Der CJ (2014) Drugging the undruggable RAS: mission possible? Nat Rev Drug Discov 13:828 851. https://doi.org/10.1038/nrd4389

Cremer T, Cremer C (2001) Chromosome territories, nuclear architecture and gene regulation in mammalian cells. Nat Rev Genet 2:292-301. https://doi.org/10.1038/35066075

Cusanovich DA, Daza R, Adey A, Pliner HA, Christiansen L, Gunderson KL, Steemers FJ, Trapnell C, Shendure J (2015) Multiplex single cell profiling of chromatin accessibility by combinatorial cellular indexing. Science 348:910-914. https://doi.org/10.1126/science. aab1601

Daniels MA, Teixeiro E, Gill J, Hausmann B, Roubaty D, Holmberg K, Werlen G, Hollander GA, Gascoigne NR, Palmer E (2006) Thymic selection threshold defined by compartmentalization of Ras/MAPK signalling. Nature 444:724-729. https://doi.org/10.1038/ nature 05269

Der CJ (2014) Are all RAS proteins created equal in cancer? National Cancer Institute. https://www.cancer.gov/research/key-initiatives/ ras/ras-central/blog/2014/ras-proteins-created-equal. Accessed Sep 222014

Desideri E, Cavallo AL, Baccarini M (2015) Alike but different: RAF paralogs and their signaling outputs. Cell 161:967-970. https://doi. org/10.1016/j.cell.2015.04.045

Dharmaiah S, Bindu L, Tran TH, Gillette WK, Frank PH, Ghirlando R, Nissley DV, Esposito D, McCormick F, Stephen AG, Simanshu DK (2016) Structural basis of recognition of farnesylated and methylated KRAS4b by PDEdelta. Proc Natl Acad Sci U S A 113:E6766E6775. https://doi.org/10.1073/pnas.1615316113

Diaz R, Ahn D, Lopez-Barcons L, Malumbres M, Perez de Castro I, Lue J, Ferrer-Miralles N, Mangues R, Tsong J, Garcia R, Perez-Soler R, Pellicer A (2002) The N-ras proto-oncogene can suppress the 
malignant phenotype in the presence or absence of its oncogene. Cancer Res 62:4514-4518

Dohlman HG, Campbell SL (2019) Regulation of large and small G proteins by ubiquitination. J Biol Chem 294:18613-18623. https:// doi.org/10.1074/jbc.REV119.011068

Dultz E, Mancini R, Polles G, Vallotton P, Alber F, Weis K (2018) Quantitative imaging of chromatin decompaction in living cells. Mol Biol Cell 29:1763-1777. https://doi.org/10.1091/mbc.E17-110648

Durrant DE, Morrison DK (2018) Targeting the Raf kinases in human cancer: the Raf dimer dilemma. Br J Cancer 118:3-8. https://doi.org/ 10.1038/bjc.2017.399

Eisenberg S, Beckett AJ, Prior IA, Dekker FJ, Hedberg C, Waldmann H, Ehrlich M, Henis YI (2011) Raft protein clustering alters N-Ras membrane interactions and activation pattern. Mol Cell Biol 31: 3938-3952. https://doi.org/10.1128/MCB.05570-11

Elad-Sfadia G, Haklai R, Balan E, Kloog Y (2004) Galectin-3 augments $\mathrm{K}$-Ras activation and triggers a Ras signal that attenuates ERK but not phosphoinositide 3-kinase activity. J Biol Chem 279:3492234930. https://doi.org/10.1074/jbc.M312697200

Farahbod M, Pavlidis P (2019) Differential coexpression in human tissues and the confounding effect of mean expression levels. Bioinformatics 35:55-61. https://doi.org/10.1093/bioinformatics/ bty538

Fetics SK, Guterres H, Kearney BM, Buhrman G, Ma B, Nussinov R, Mattos C (2015) Allosteric effects of the oncogenic RasQ61L mutant on Raf-RBD. Structure 23:505-516. https://doi.org/10.1016/j. str.2014.12.017

Fivaz M, Meyer T (2005) Reversible intracellular translocation of KRas but not HRas in hippocampal neurons regulated by $\mathrm{Ca} 2+/$ calmodulin. J Cell Biol 170:429-441. https://doi.org/10.1083/jcb. 200409157

Frauenfelder H, Sligar SG, Wolynes PG (1991) The energy landscapes and motions of proteins. Science 254:1598-1603. https://doi.org/10. 1126/science. 1749933

Freeman AK, Ritt DA, Morrison DK (2013a) Effects of Raf dimerization and its inhibition on normal and disease-associated Raf signaling. Mol Cell 49:751-758. https://doi.org/10.1016/j.molcel.2012.12.018

Freeman AK, Ritt DA, Morrison DK (2013b) The importance of Raf dimerization in cell signaling. Small GTPases 4:180-185. https:// doi.org/10.4161/sgtp.26117

Garcia-Gomez R, Bustelo XR, Crespo P (2018) Protein-protein interactions: emerging oncotargets in the RAS-ERK pathway. Trends Cancer 4:616-633. https://doi.org/10.1016/j.trecan.2018.07.002

Garcia-Ibanez Y, Riesco-Eizaguirre G, Santisteban P, Casar B, Crespo P (2020) RAS subcellular localization inversely regulates thyroid tumor growth and dissemination. Cancers (Basel) 12:2588. https://doi. org/10.3390/cancers 12092588

Ghosh S, Xie WQ, Quest AF, Mabrouk GM, Strum JC, Bell RM (1994) The cysteine-rich region of raf- 1 kinase contains zinc, translocates to liposomes, and is adjacent to a segment that binds GTP-ras. J Biol Chem 269:10000-10007. https://doi.org/10.1016/S0021-9258(17) 36981-8

Haigis KM, Kendall KR, Wang Y, Cheung A, Haigis MC, Glickman JN, Niwa-Kawakita M, Sweet-Cordero A, Sebolt-Leopold J, Shannon KM, Settleman J, Giovannini M, Jacks T (2008) Differential effects of oncogenic K-Ras and N-Ras on proliferation, differentiation and tumor progression in the colon. Nat Genet 40:600-608. https://doi. org/10.1038/ng.115

Haigis KM, Cichowski K, Elledge SJ (2019) Tissue-specificity in cancer: the rule, not the exception. Science 363:1150-1151. https://doi.org/ 10.1126/science.aaw3472

Hancock JF, Magee AI, Childs JE, Marshall CJ (1989) All ras proteins are polyisoprenylated but only some are palmitoylated. Cell 57: 1167-1177. https://doi.org/10.1016/0092-8674(89)90054-8
Hatzivassiliou G, Song K, Yen I, Brandhuber BJ, Anderson DJ, Alvarado R, Ludlam MJ, Stokoe D, Gloor SL, Vigers G, Morales T, Aliagas I, Liu B, Sideris S, Hoeflich KP, Jaiswal BS, Seshagiri S, Koeppen H, Belvin M, Friedman LS, Malek S (2010) RAF inhibitors prime wildtype RAF to activate the MAPK pathway and enhance growth. Nature 464:431-435. https://doi.org/10.1038/nature08833

Heidorn SJ, Milagre C, Whittaker S, Nourry A, Niculescu-Duvas I, Dhomen N, Hussain J, Reis-Filho JS, Springer CJ, Pritchard C, Marais R (2010) Kinase-dead BRAF and oncogenic RAS cooperate to drive tumor progression through CRAF. Cell 140:209-221. https://doi.org/10.1016/j.cell.2009.12.040

Heppner DE, Eck MJ (2021) A structural perspective on targeting the RTK/Ras/MAP kinase pathway in cancer. Protein Sci. 30:15351553. https://doi.org/10.1002/pro.4125

Hinde E, Cardarelli F, Digman MA, Gratton E (2012) Changes in chromatin compaction during the cell cycle revealed by micrometerscale measurement of molecular flow in the nucleus. Biophys $\mathrm{J}$ 102:691-697. https://doi.org/10.1016/j.bpj.2011.11.4026

Hobbs GA, Der CJ, Rossman KL (2016) RAS isoforms and mutations in cancer at a glance. J Cell Sci 129:1287-1292. https://doi.org/10. $1242 /$ jcs. 182873

Honore B (2020) Proteomic protocols for differential protein expression analyses. Methods Mol Biol 2110:47-58. https://doi.org/10.1007/ 978-1-0716-0255-3_3

Hu J, Stites EC, Yu H, Germino EA, Meharena HS, Stork PJS, Kornev AP, Taylor SS, Shaw AS (2013) Allosteric activation of functionally asymmetric RAF kinase dimers. Cell 154:1036-1046. https://doi. org/10.1016/j.cell.2013.07.046

Imielinski M, Greulich H, Kaplan B, Araujo L, Amann J, Horn L, Schiller J, Villalona-Calero MA, Meyerson M, Carbone DP (2014) Oncogenic and sorafenib-sensitive ARAF mutations in lung adenocarcinoma. J Clin Invest 124:1582-1586. https://doi.org/10.1172/ JCI72763

Ise K, Nakamura K, Nakao K, Shimizu S, Harada H, Ichise T, Miyoshi J, Gondo Y, Ishikawa T, Aiba A, Katsuki M (2000) Targeted deletion of the H-ras gene decreases tumor formation in mouse skin carcinogenesis. Oncogene 19:2951-2956. https://doi.org/10.1038/sj.onc. 1203600

Jambrina PG, Rauch N, Pilkington R, Rybakova K, Nguyen LK, Kholodenko BN, Buchete NV, Kolch W, Rosta E (2016) Phosphorylation of RAF kinase dimers drives conformational changes that facilitate transactivation. Angew Chem Int Ed Eng 55:983-986. https://doi.org/10.1002/anie.201509272

Jang H, Abraham SJ, Chavan TS, Hitchinson B, Khavrutskii L, Tarasova NI, Nussinov R, Gaponenko V (2015) Mechanisms of membrane binding of small GTPase K-Ras4B farnesylated hypervariable region. J Biol Chem 290:9465-9477. https://doi.org/10.1074/jbc. M114.620724

Jang H, Banerjee A, Chavan TS, Lu S, Zhang J, Gaponenko V, Nussinov $\mathrm{R}$ (2016a) The higher level of complexity of K-Ras4B activation at the membrane. FASEB J 30:1643-1655. https://doi.org/10.1096/fj. 15-279091

Jang H, Muratcioglu S, Gursoy A, Keskin O, Nussinov R (2016b) Membrane-associated Ras dimers are isoform-specific: K-Ras dimers differ from H-Ras dimers. Biochem J 473:1719-1732. https://doi.org/10.1042/BCJ20160031

Jang H, Banerjee A, Chavan T, Gaponenko V, Nussinov R (2017) Flexible-body motions of calmodulin and the farnesylated hypervariable region yield a high-affinity interaction enabling K-Ras4B membrane extraction. J Biol Chem 292:12544-12559. https://doi. org/10.1074/jbc.M117.785063

Jang H, Banerjee A, Marcus K, Makowski L, Mattos C, Gaponenko V, Nussinov R (2019) The structural basis of the farnesylated and methylated KRas4B interaction with calmodulin. Structure 27(1647-1659):e1644. https://doi.org/10.1016/j.str.2019.08.009 
Jang H, Zhang M, Nussinov R (2020) The quaternary assembly of KRas4B with Raf-1 at the membrane. Comput Struct Biotechnol J 18:737-748. https://doi.org/10.1016/j.csbj.2020.03.018

Jin T, Lavoie H, Sahmi M, David M, Hilt C, Hammell A, Therrien M (2017) RAF inhibitors promote RAS-RAF interaction by allosterically disrupting RAF autoinhibition. Nat Commun 8:1211. https:// doi.org/10.1038/s41467-017-01274-0

Jinesh GG, Sambandam V, Vijayaraghavan S, Balaji K, Mukherjee S (2018) Molecular genetics and cellular events of K-Ras-driven tumorigenesis. Oncogene 37:839-846. https://doi.org/10.1038/onc. 2017.377

Joyal JL, Burks DJ, Pons S, Matter WF, Vlahos CJ, White MF, Sacks DB (1997) Calmodulin activates phosphatidylinositol 3-kinase. J Biol Chem 272:28183-28186. https://doi.org/10.1074/jbc.272.45.28183

Karemaker ID, Vermeulen M (2018) Single-cell DNA methylation profiling: technologies and biological applications. Trends Biotechnol 36:952-965. https://doi.org/10.1016/j.tibtech.2018.04.002

Karreth FA, Frese KK, DeNicola GM, Baccarini M, Tuveson DA (2011) $\mathrm{C}$-Raf is required for the initiation of lung cancer by K-Ras(G12D). Cancer Discov 1:128-136. https://doi.org/10.1158/2159-8290.CD10-0044

Kattan WE, Hancock JF (2020) RAS Function in cancer cells: translating membrane biology and biochemistry into new therapeutics. Biochem J 477:2893-2919. https://doi.org/10.1042/BCJ20190839

Klein CH, Truxius DC, Vogel HA, Harizanova J, Murarka S, MartinGago P, Bastiaens PIH (2019) PDEdelta inhibition impedes the proliferation and survival of human colorectal cancer cell lines harboring oncogenic KRas. Int J Cancer 144:767-776. https://doi.org/ 10.1002/ijc.31859

Klemm SL, Shipony Z, Greenleaf WJ (2019) Chromatin accessibility and the regulatory epigenome. Nat Rev Genet 20:207-220. https://doi. org/10.1038/s41576-018-0089-8

Kocher HM, Senkus R, Moorhead J, Al-Nawab M, Patel AG, Benjamin IS, Hendry BM (2005) Expression of Ras GTPase isoforms in normal and diseased pancreas. Pancreatology 5:205-214. https://doi. org/10.1159/000085273

Kondo Y, Ognjenovic J, Banerjee S, Karandur D, Merk A, Kulhanek K, Wong K, Roose JP, Subramaniam S, Kuriyan J (2019) Cryo-EM structure of a dimeric B-Raf:14-3-3 complex reveals asymmetry in the active sites of B-Raf kinases. Science 366:109-115. https://doi. org/10.1126/science.aay0543

Kong G, Chang YI, Damnernsawad A, You X, Du J, Ranheim EA, Lee W, Ryu MJ, Zhou Y, Xing Y, Chang Q, Burd CE, Zhang J (2016) Loss of wild-type Kras promotes activation of all Ras isoforms in oncogenic Kras-induced leukemogenesis. Leukemia 30:1542-1551. https://doi.org/10.1038/leu.2016.40

Kosti I, Jain N, Aran D, Butte AJ, Sirota M (2016) Cross-tissue analysis of gene and protein expression in normal and cancer tissues. Sci Rep 6:24799. https://doi.org/10.1038/srep24799

Kuchler P, Zimmermann G, Winzker M, Janning P, Waldmann H, Ziegler S (2018) Identification of novel PDEdelta interacting proteins. Bioorg Med Chem 26:1426-1434. https://doi.org/10.1016/j. bmc.2017.08.033

Kumar S, Ma B, Tsai CJ, Sinha N, Nussinov R (2000) Folding and binding cascades: dynamic landscapes and population shifts. Protein Sci 9:10-19. https://doi.org/10.1110/ps.9.1.10

Lafon-Hughes L, Di Tomaso MV, Mendez-Acuna L, Martinez-Lopez W (2008) Chromatin-remodelling mechanisms in cancer. Mutat Res 658:191-214. https://doi.org/10.1016/j.mrrev.2008.01.008

Lahnemann D, Koster J, Szczurek E, McCarthy DJ, Hicks SC, Robinson MD, Vallejos CA, Campbell KR, Beerenwinkel N, Mahfouz A, Pinello L, Skums P, Stamatakis A, Attolini CS, Aparicio S, Baaijens J, Balvert M, Barbanson B, Cappuccio A, Corleone G, Dutilh BE, Florescu M, Guryev V, Holmer R, Jahn K, Lobo TJ, Keizer EM, Khatri I, Kielbasa SM, Korbel JO, Kozlov AM, Kuo TH, Lelieveldt BPF, Mandoiu II, Marioni JC, Marschall T, Molder
F, Niknejad A, Raczkowski L, Reinders M, Ridder J, Saliba AE, Somarakis A, Stegle O, Theis FJ, Yang H, Zelikovsky A, McHardy AC, Raphael BJ, Shah SP, Schonhuth A (2020) Eleven grand challenges in single-cell data science. Genome Biol 21:31. https://doi. org/10.1186/s13059-020-1926-6

Lampson BL, Pershing NL, Prinz JA, Lacsina JR, Marzluff WF, Nicchitta CV, MacAlpine DM, Counter CM (2013) Rare codons regulate KRas oncogenesis. Curr Biol 23:70-75. https://doi.org/10. 1016/j.cub.2012.11.031

Lavoie H, Therrien M (2015) Regulation of RAF protein kinases in ERK signalling. Nat Rev Mol Cell Biol 16:281-298. https://doi.org/10. 1038/nrm3979

Lavoie H, Thevakumaran N, Gavory G, Li JJ, Padeganeh A, Guiral S, Duchaine J, Mao DY, Bouvier M, Sicheri F, Therrien M (2013) Inhibitors that stabilize a closed RAF kinase domain conformation induce dimerization. Nat Chem Biol 9:428-436. https://doi.org/10. 1038/nchembio. 1257

Lavoie H, Sahmi M, Maisonneuve P, Marullo SA, Thevakumaran N, Jin T, Kurinov I, Sicheri F, Therrien M (2018) MEK drives BRAF activation through allosteric control of KSR proteins. Nature 554: 549-553. https://doi.org/10.1038/nature25478

Lavoie H, Gagnon J, Therrien M (2020) ERK signalling: a master regulator of cell behaviour, life and fate. Nat Rev Mol Cell Biol 21:607632. https://doi.org/10.1038/s41580-020-0255-7

Lee Y, Phelps C, Huang T, Mostofian B, Wu L, Zhang Y, Tao K, Chang YH, Stork PJ, Gray JW, Zuckerman DM, Nan X (2019) Highthroughput, single-particle tracking reveals nested membrane domains that dictate $\mathrm{KRas}(\mathrm{G} 12 \mathrm{D})$ diffusion and trafficking. Elife 8: e46393. https://doi.org/10.7554/eLife.46393

Li S, Balmain A, Counter CM (2018a) A model for RAS mutation patterns in cancers: finding the sweet spot. Nat Rev Cancer 18:767777. https://doi.org/10.1038/s41568-018-0076-6

Li S, Jang H, Zhang J, Nussinov R (2018b) Raf-1 cysteine-rich domain increases the affinity of $\mathrm{K}-\mathrm{Ras} / \mathrm{Raf}$ at the membrane, promoting MAPK signaling. Structure 26(513-525):e512. https://doi.org/10. 1016/j.str.2018.01.011

Li Y, Liu Y, Yang H, Zhang T, Naruse K, Tu Q (2020a) Dynamic transcriptional and chromatin accessibility landscape of medaka embryogenesis. Genome Res 30:924-937. https://doi.org/10.1101/gr. 258871.119

Li YC, Lytle NK, Gammon ST, Wang L, Hayes TK, Sutton MN, Bast RC Jr, Der CJ, Piwnica-Worms D, McCormick F, Wahl GM (2020b) Analysis of RAS protein interactions in living cells reveals a mechanism for pan-RAS depletion by membrane-targeted RAS binders. Proc Natl Acad Sci U S A 117:12121-12130. https://doi.org/10. 1073/pnas.2000848117

Lleres D, James J, Swift S, Norman DG, Lamond AI (2009) Quantitative analysis of chromatin compaction in living cells using FLIM-FRET. J Cell Biol 187:481-496. https://doi.org/10.1083/jcb.200907029

Lorch Y, Kornberg RD (2017) Chromatin-remodeling for transcription. Q Rev Biophys 50:e5. https://doi.org/10.1017/ S003358351700004X

Lu S, Banerjee A, Jang H, Zhang J, Gaponenko V, Nussinov R (2015) GTP Binding and oncogenic mutations may attenuate hypervariable region (HVR)-catalytic domain interactions in small GTPase KRas4B, exposing the effector binding site. J Biol Chem 290: 28887-28900. https://doi.org/10.1074/jbc.M115.664755

Lu S, Jang H, Muratcioglu S, Gursoy A, Keskin O, Nussinov R, Zhang J (2016) Ras conformational ensembles, allostery, and signaling. Chem Rev 116:6607-6665. https://doi.org/10.1021/acs.chemrev. $5 \mathrm{~b} 00542$

Magana-Acosta M, Valadez-Graham V (2020) Chromatin remodelers in the $3 \mathrm{D}$ nuclear compartment. Front Genet 11:600615. https://doi. org/10.3389/fgene.2020.600615

Matallanas D, Romano D, Al-Mulla F, O’Neill E, Al-Ali W, Crespo P, Doyle B, Nixon C, Sansom O, Drosten M, Barbacid M, Kolch W 
(2011) Mutant K-Ras activation of the proapoptotic MST2 pathway is antagonized by wild-type K-Ras. Mol Cell 44:893-906. https:// doi.org/10.1016/j.molcel.2011.10.016

Maurer G, Tarkowski B, Baccarini M (2011) Raf kinases in cancer-roles and therapeutic opportunities. Oncogene 30:3477-3488. https://doi. org/10.1038/onc.2011.160

Minnoye L, Marinov GK, Krausgruber T, Pan L, Marand AP, Secchia S, Greenleaf WJ, Furlong EEM, Zhao K, Schmitz RJ, Bock C, Aerts S (2021) Chromatin accessibility profiling methods. Nat Rev Methods Primers 1:10. https://doi.org/10.1038/s43586-020-00008-9

Mo SP, Coulson JM, Prior IA (2018) RAS variant signalling. Biochem Soc Trans 46:1325-1332. https://doi.org/10.1042/BST20180173

Morgan MA, Shilatifard A (2015) Chromatin signatures of cancer. Genes Dev 29:238-249. https://doi.org/10.1101/gad.255182.114

Munoz-Maldonado C, Zimmer Y, Medova M (2019) A comparative analysis of individual RAS mutations in cancer biology. Front Oncol 9:1088. https://doi.org/10.3389/fonc.2019.01088

Muratcioglu S, Jang H, Gursoy A, Keskin O, Nussinov R (2017) PDE $\delta$ binding to Ras isoforms provides a route to proper membrane localization. J Phys Chem B 121:5917-5927. https://doi.org/10.1021/ acs.jpcb.7b03035

Muratcioglu S, Aydin C, Odabasi E, Ozdemir ES, Firat-Karalar EN, Jang H, Tsai CJ, Nussinov R, Kavakli IH, Gursoy A, Keskin O (2020) Oncogenic K-Ras4B dimerization enhances downstream mitogenactivated protein kinase signaling. J Mol Biol 432:1199-1215. https://doi.org/10.1016/j.jmb.2020.01.002

Nakhaeizadeh H, Amin E, Nakhaei-Rad S, Dvorsky R, Ahmadian MR (2016) The RAS-effector interface: isoform-specific differences in the effector binding regions. PLoS One 11:e0167145. https://doi. org/10.1371/journal.pone.0167145

Nan X, Tamguney TM, Collisson EA, Lin LJ, Pitt C, Galeas J, Lewis S, Gray JW, McCormick F, Chu S (2015) Ras-GTP dimers activate the mitogen-activated protein kinase (MAPK) pathway. Proc Natl Acad Sci U S A 112:7996-8001. https://doi.org/10.1073/pnas. 1509123112

Newlaczyl AU (2016) Isoform-specific Ras expression and signalling. Doctor of Philosophy thesis, University of Liverpool. 10.17638/ 03000021

Newlaczyl AU, Coulson JM, Prior IA (2017) Quantification of spatiotemporal patterns of Ras isoform expression during development. Sci Rep 7:41297. https://doi.org/10.1038/srep41297

Nir G, Farabella I, Perez Estrada C, Ebeling CG, Beliveau BJ, Sasaki HM, Lee SD, Nguyen SC, McCole RB, Chattoraj S, Erceg J, AlHaj Abed J, Martins NMC, Nguyen HQ, Hannan MA, Russell S, Durand NC, Rao SSP, Kishi JY, Soler-Vila P, Di Pierro M, Onuchic JN, Callahan SP, Schreiner JM, Stuckey JA, Yin P, Aiden EL, Marti-Renom MA, Wu CT (2018) Walking along chromosomes with super-resolution imaging, contact maps, and integrative modeling. PLoS Genet 14:e1007872. https://doi.org/10.1371/ journal.pgen.1007872

Nothjunge S, Nuhrenberg TG, Gruning BA, Doppler SA, Preissl S, Schwaderer M, Rommel C, Krane M, Hein L, Gilsbach R (2017) DNA methylation signatures follow preformed chromatin compartments in cardiac myocytes. Nat Commun 8:1667. https://doi.org/10. 1038/s41467-017-01724-9

Nussinov R (2016) Introduction to protein ensembles and allostery. Chem Rev 116:6263-6266. https://doi.org/10.1021/acs.chemrev. $6 \mathrm{~b} 00283$

Nussinov R, Jang H, Tsai CJ (2015) Oligomerization and nanocluster organization render specificity. Biol Rev Camb Philos Soc 90: 587-598. https://doi.org/10.1111/brv.12124

Nussinov R, Tsai CJ, Chakrabarti M, Jang H (2016) A new view of Ras isoforms in cancers. Cancer Res 76:18-23. https://doi.org/10.1158/ 0008-5472.CAN-15-1536
Nussinov R, Tsai CJ, Jang H (2017) A new view of pathway-driven drug resistance in tumor proliferation. Trends Pharmacol Sci 38:427-437. https://doi.org/10.1016/j.tips.2017.02.001

Nussinov R, Tsai CJ, Jang H (2018a) Oncogenic Ras isoforms signaling specificity at the membrane. Cancer Res 78:593-602. https://doi. org/10.1158/0008-5472.CAN-17-2727

Nussinov R, Zhang M, Tsai CJ, Liao TJ, Fushman D, Jang H (2018b) Autoinhibition in Ras effectors Raf, PI3Kalpha, and RASSF5: a comprehensive review underscoring the challenges in pharmacological intervention. Biophys Rev 10:1263-1282. https://doi.org/10. 1007/s12551-018-0461-0

Nussinov R, Tsai CJ, Jang H (2019a) Is Nanoclustering essential for all oncogenic KRas pathways? Can it explain why wild-type KRas can inhibit its oncogenic variant? Semin Cancer Biol 54:114-120. https://doi.org/10.1016/j.semcancer.2018.01.002

Nussinov R, Tsai CJ, Jang H (2019b) Oncogenic KRas mobility in the membrane and signaling response. Semin Cancer Biol 54:109-113. https://doi.org/10.1016/j.semcancer.2018.02.009

Nussinov R, Jang H, Zhang M, Tsai CJ, Sablina AA (2020a) The Mystery of Rap1 Suppression of oncogenic Ras. Trends Cancer 6:369-379. https://doi.org/10.1016/j.trecan.2020.02.002

Nussinov R, Tsai CJ, Jang H (2020b) Are parallel proliferation pathways redundant? Trends Biochem Sci 45:554-563. https://doi.org/10. 1016/j.tibs.2020.03.013

Nussinov R, Tsai CJ, Jang H (2020c) Autoinhibition can identify rare driver mutations and advise pharmacology. FASEB J 34:16-29. https://doi.org/10.1096/fj.201901341R

Nussinov R, Jang H, Nir G, Tsai CJ, Cheng FX (2021) A new precision medicine initiative at the dawn of exascale computing. Signal Transduct Tar 6:3. https://doi.org/10.1038/s41392-020-00420-3

Onken B, Wiener H, Philips MR, Chang EC (2006) Compartmentalized signaling of Ras in fission yeast. Proc Natl Acad Sci U S A 103: 9045-9050. https://doi.org/10.1073/pnas.0603318103

Papantonis A, Cook PR (2013) Transcription factories: genome organization and gene regulation. Chem Rev 113:8683-8705. https://doi. org/10.1021/cr300513p

Park E, Rawson S, Li K, Kim BW, Ficarro SB, Pino GG, Sharif H, Marto JA, Jeon H, Eck MJ (2019) Architecture of autoinhibited and active BRAF-MEK1-14-3-3 complexes. Nature 575:545-550. https://doi. org/10.1038/s41586-019-1660-y

Pellicer A (2011) RAS genes. Encyclopedia of Cancer, Springer, Berlin, Heidelberg. https://doi.org/10.1007/978-3-642-16483-5_4951

Pfister S, Janzarik WG, Remke M, Ernst A, Werft W, Becker N, Toedt G, Wittmann A, Kratz C, Olbrich H, Ahmadi R, Thieme B, Joos S, Radlwimmer B, Kulozik A, Pietsch T, Herold-Mende C, Gnekow A, Reifenberger G, Korshunov A, Scheurlen W, Omran H, Lichter P (2008) BRAF gene duplication constitutes a mechanism of MAPK pathway activation in low-grade astrocytomas. J Clin Invest 118: 1739-1749. https://doi.org/10.1172/JCI33656

Poulikakos PI, Zhang C, Bollag G, Shokat KM, Rosen N (2010) RAF inhibitors transactivate RAF dimers and ERK signalling in cells with wild-type BRAF. Nature 464:427-430. https://doi.org/10.1038/ nature 08902

Poulin EJ, Bera AK, Lu J, Lin YJ, Strasser SD, Paulo JA, Huang TQ, Morales C, Yan W, Cook J, Nowak JA, Brubaker DK, Joughin BA Johnson CW, DeStefanis RA, Ghazi PC, Gondi S, Wales TE, Iacob RE, Bogdanova L, Gierut JJ, Li Y, Engen JR, Perez-Mancera PA, Braun BS, Gygi SP, Lauffenburger DA, Westover KD, Haigis KM (2019) Tissue-specific oncogenic activity of KRAS(A146T). Cancer Discov 9:738-755. https://doi.org/10.1158/2159-8290.CD$18-1220$

Prior IA, Lewis PD, Mattos C (2012) A comprehensive survey of Ras mutations in cancer. Cancer Res 72:2457-2467. https://doi.org/10. 1158/0008-5472.CAN-11-2612 
Prior IA, Hood FE, Hartley JL (2020) The frequency of Ras mutations in cancer. Cancer Res 80:2969-2974. https://doi.org/10.1158/00085472.CAN-19-3682

Qiu W, Sahin F, Iacobuzio-Donahue CA, Garcia-Carracedo D, Wang WM, Kuo CY, Chen D, Arking DE, Lowy AM, Hruban RH, Remotti HE, Su GH (2011) Disruption of p16 and activation of Kras in pancreas increase ductal adenocarcinoma formation and metastasis in vivo. Oncotarget 2:862-873. https://doi.org/10. 18632/oncotarget.357

Rajakulendran T, Sahmi M, Lefrancois M, Sicheri F, Therrien M (2009) A dimerization-dependent mechanism drives RAF catalytic activation. Nature 461:542-545. https://doi.org/10.1038/nature08314

Rajasekharan SK, Raman T (2013) Ras and Ras mutations in cancer. Central European Journal of Biology 8:609-624. https://doi.org/ 10.2478/s11535-013-0158-5

Randic T, Kozar I, Margue C, Utikal J, Kreis S (2021) NRAS mutant melanoma: towards better therapies. Cancer Treat Rev 99:102238. https://doi.org/10.1016/j.ctrv.2021.102238

Raso E (2020) Splice variants of RAS-translational significance. Cancer Metastasis Rev 39:1039-1049. https://doi.org/10.1007/s10555-02009920-8

Rauen KA (2013) The RASopathies. Annu Rev Genomics Hum Genet 14:355-369. https://doi.org/10.1146/annurev-genom-091212153523

Rezaei Adariani S, Buchholzer M, Akbarzadeh M, Nakhaei-Rad S, Dvorsky R, Ahmadian MR (2018) Structural snapshots of RAF kinase interactions. Biochem Soc Trans 46:1393-1406. https://doi. org/10.1042/BST20170528

Ritt DA, Monson DM, Specht SI, Morrison DK (2010) Impact of feedback phosphorylation and Raf heterodimerization on normal and mutant B-Raf signaling. Mol Cell Biol 30:806-819. https://doi. org/10.1128/MCB.00569-09

Rolicka A, Guo Y, Ganez Zapater A, Tariq K, Quin J, Vintermist A, Sadeghifar F, Arsenian-Henriksson M, Ostlund Farrants AK (2020) The chromatin-remodeling complexes B-WICH and NuRD regulate ribosomal transcription in response to glucose. FASEB J 34:10818-10834. https://doi.org/10.1096/fj.202000411R

Rosa-Garrido M, Chapski DJ, Schmitt AD, Kimball TH, Karbassi E, Monte E, Balderas E, Pellegrini M, Shih TT, Soehalim E, Liem D, Ping P, Galjart NJ, Ren S, Wang Y, Ren B, Vondriska TM (2017) High-resolution mapping of chromatin conformation in cardiac myocytes reveals structural remodeling of the epigenome in heart failure. Circulation 136:1613-1625. https://doi.org/10.1161/ CIRCULATIONAHA.117.029430

Russo AL, Borger DR, Szymonifka J, Ryan DP, Wo JY, Blaszkowsky LS, Kwak EL, Allen JN, Wadlow RC, Zhu AX, Murphy JE, Faris JE, Dias-Santagata D, Haigis KM, Ellisen LW, Iafrate AJ, Hong TS (2014) Mutational analysis and clinical correlation of metastatic colorectal cancer. Cancer 120:1482-1490. https://doi.org/10.1002/ cncr.28599

Sack LM, Davoli T, Li MZ, Li Y, Xu Q, Naxerova K, Wooten EC, Bernardi RJ, Martin TD, Chen T, Leng Y, Liang AC, Scorsone KA, Westbrook TF, Wong KK, Elledge SJ (2018) Profound tissue specificity in proliferation control underlies cancer drivers and aneuploidy patterns. Cell 173(499-514):e423. https://doi.org/10.1016/ j.cell.2018.02.037

Sasaki AT, Carracedo A, Locasale JW, Anastasiou D, Takeuchi K, Kahoud ER, Haviv S, Asara JM, Pandolfi PP, Cantley LC 2011 Ubiquitination of K-Ras enhances activation and facilitates binding to select downstream effectors. Sci Signal 4:ra13. https://doi.org/10. 1126/scisignal.2001518

Schmick M, Vartak N, Papke B, Kovacevic M, Truxius DC, Rossmannek L, Bastiaens PIH (2014) KRas localizes to the plasma membrane by spatial cycles of solubilization, trapping and vesicular transport. Cell 157:459-471. https://doi.org/10.1016/j.cell.2014.02.051
Schuhmacher AJ, Guerra C, Sauzeau V, Canamero M, Bustelo XR, Barbacid M (2008) A mouse model for Costello syndrome reveals an Ang II-mediated hypertensive condition. J Clin Invest 118:21692179. https://doi.org/10.1172/JCI34385

Shalom-Feuerstein R, Cooks T, Raz A, Kloog Y (2005) Galectin-3 regulates a molecular switch from N-Ras to K-Ras usage in human breast carcinoma cells. Cancer Res 65:7292-7300. https://doi.org/ 10.1158/0008-5472.CAN-05-0775

Shaw AS, Kornev AP, Hu J, Ahuja LG, Taylor SS (2014) Kinases and pseudokinases: lessons from RAF. Mol Cell Biol 34:1538-1546. https://doi.org/10.1128/MCB.00057-14

Sidhu RS, Clough RR, Bhullar RP (2003) Ca2+/calmodulin binds and dissociates K-RasB from membrane. Biochem Biophys Res Commun 304:655-660. https://doi.org/10.1016/s0006-291x(03) 00635-1

Sieburth DS, Sun Q, Han M (1998) SUR-8, a conserved Ras-binding protein with leucine-rich repeats, positively regulates Rasmediated signaling in C. elegans. Cell 94:119-130. https://doi.org/ 10.1016/s0092-8674(00)81227-1

Smith SF, Collins SE, Charest PG (2020) Ras, PI3K and mTORC2three's a crowd? J Cell Sci 133:jcs234930. https://doi.org/10.1242/ jes. 234930

Sosnik J, Vieira WA, Webster KA, Siegfried KR, McCusker CD (2017) A new and improved algorithm for the quantification of chromatin condensation from microscopic data shows decreased chromatin condensation in regenerating axolotl limb cells. PLoS One 12: e0185292. https://doi.org/10.1371/journal.pone.0185292

Spandidos DA, Frame M, Wilkie NM (1990) Expression of the normal $\mathrm{H}$-ras1 gene can suppress the transformed and tumorigenic phenotypes induced by mutant ras genes. Anticancer Res 10:1543-1554

Sperlich B, Kapoor S, Waldmann H, Winter R, Weise K (2016) Regulation of K-Ras4B membrane binding by calmodulin. Biophys J 111:113-122. https://doi.org/10.1016/j.bpj.2016.05.042

Staffas A, Karlsson C, Persson M, Palmqvist L, Bergo MO (2015) Wildtype KRAS inhibits oncogenic KRAS-induced T-ALL in mice. Leukemia 29:1032-1040. https://doi.org/10.1038/leu.2014.315

Stephens RM, Yi M, Kessing B, Nissley DV, McCormick F (2017) Tumor RAS gene expression levels are influenced by the mutational status of RAS genes and both upstream and downstream RAS pathway genes. Cancer Informat 16:1176935117711944. https://doi.org/ $10.1177 / 1176935117711944$

Szabo Q, Bantignies F, Cavalli G (2019) Principles of genome folding into topologically associating domains. Sci Adv 5:eaaw1668. https://doi.org/10.1126/sciadv.aaw1668

Terrell EM, Morrison DK (2019) Ras-mediated activation of the Raf family kinases. Cold Spring Harb Perspect Med 9:a033746. https://doi.org/10.1101/cshperspect.a033746

Terrell EM, Durrant DE, Ritt DA, Sealover NE, Sheffels E, SpencerSmith R, Esposito D, Zhou Y, Hancock JF, Kortum RL, Morrison DK (2019) Distinct binding preferences between Ras and Raf family members and the impact on oncogenic Ras signaling. Mol Cell 76(872-884):e875. https://doi.org/10.1016/j.molcel.2019.09.004

Thevathasan JV, Tan E, Zheng H, Lin YC, Li Y, Inoue T, Fivaz M (2013) The small GTPase HRas shapes local PI3K signals through positive feedback and regulates persistent membrane extension in migrating fibroblasts. Mol Biol Cell 24:2228-2237. https://doi.org/10.1091/ mbc.E12-12-0905

To MD, Wong CE, Karnezis AN, Del Rosario R, Di Lauro R, Balmain A (2008) Kras regulatory elements and exon 4A determine mutation specificity in lung cancer. Nat Genet 40:1240-1244. https://doi.org/ 10.1038/ng.211

To MD, Rosario RD, Westcott PM, Banta KL, Balmain A (2013) Interactions between wild-type and mutant Ras genes in lung and skin carcinogenesis. Oncogene 32:4028-4033. https://doi.org/10. 1038/onc.2012.404 
Travers T, Lopez CA, Van QN, Neale C, Tonelli M, Stephen AG, Gnanakaran S (2018) Molecular recognition of RAS/RAF complex at the membrane: role of RAF cysteine-rich domain. Sci Rep 8: 8461. https://doi.org/10.1038/s41598-018-26832-4

Tsai CJ, Nussinov R (2018) Allosteric activation of RAF in the MAPK signaling pathway. Curr Opin Struct Biol 53:100-106. https://doi. org/10.1016/j.sbi.2018.07.007

Tsai CJ, Kumar S, Ma B, Nussinov R (1999) Folding funnels, binding funnels, and protein function. Protein Sci 8:1181-1190. https://doi. org/10.1110/ps.8.6.1181

Tsai FD, Lopes MS, Zhou M, Court H, Ponce O, Fiordalisi JJ, Gierut JJ, Cox AD, Haigis KM, Philips MR (2015) K-Ras4A splice variant is widely expressed in cancer and uses a hybrid membrane-targeting motif. Proc Natl Acad Sci U S A 112:779-784. https://doi.org/10. 1073/pnas.1412811112

Udell CM, Rajakulendran T, Sicheri F, Therrien M (2011) Mechanistic principles of RAF kinase signaling. Cell Mol Life Sci 68:553-565. https://doi.org/10.1007/s00018-010-0520-6

Ullah R, Yin Q, Snell AH, Wan L (2021) RAF-MEK-ERK pathway in cancer evolution and treatment. Semin Cancer Biol. https://doi.org/ 10.1016/j.semcancer.2021.05.010

Varga A, Ehrenreiter K, Aschenbrenner B, Kocieniewski P, Kochanczyk M, Lipniacki T, Baccarini M (2017) RAF1/BRAF dimerization integrates the signal from RAS to ERK and ROKalpha. Sci Signal 10: eaai8482. https://doi.org/10.1126/scisignal.aai8482

Verkhivker GM (2016) Molecular dynamics simulations and modelling of the residue interaction networks in the BRAF kinase complexes with small molecule inhibitors: probing the allosteric effects of ligand-induced kinase dimerization and paradoxical activation. Mol BioSyst 12:3146-3165. https://doi.org/10.1039/c6mb00298f

Vigil D, Cherfils J, Rossman KL, Der CJ (2010) Ras superfamily GEFs and GAPs: validated and tractable targets for cancer therapy? Nat Rev Cancer 10:842-857. https://doi.org/10.1038/nrc2960

Villalonga P, Lopez-Alcala C, Bosch M, Chiloeches A, Rocamora N, Gil J, Marais R, Marshall CJ, Bachs O, Agell N (2001) Calmodulin binds to K-Ras, but not to H- or N-Ras, and modulates its downstream signaling. Mol Cell Biol 21:7345-7354. https://doi.org/10. 1128/MCB.21.21.7345-7354.2001

Wachsmuth M, Knoch TA, Rippe K (2016) Dynamic properties of independent chromatin domains measured by correlation spectroscopy in living cells. Epigenetics Chromatin 9:57. https://doi.org/10.1186/ s13072-016-0093-1

Wang MT, Holderfield M, Galeas J, Delrosario R, To MD, Balmain A, McCormick F (2015) K-Ras promotes tumorigenicity through suppression of non-canonical Wnt signaling. Cell 163:1237-1251. https://doi.org/10.1016/j.cell.2015.10.041

Wang G, Zhang M, Jang H, Lu S, Lin S, Chen G, Nussinov R, Zhang J, Gaponenko V (2018) Interaction of calmodulin with the cSH2 domain of the p85 regulatory subunit. Biochemistry 57:1917-1928. https://doi.org/10.1021/acs.biochem.7b01130

Wei G, Xi W, Nussinov R, Ma B (2016) Protein ensembles: how does nature harness thermodynamic fluctuations for life? The diverse functional roles of conformational ensembles in the cell. Chem Rev 116:6516-6551. https://doi.org/10.1021/acs.chemrev.5b00562

Wolfman A (2001) Ras isoform-specific signaling: location, location, location. Sci STKE 2001:pe2. https://doi.org/10.1126/stke.2001. 96.pe2

Wu LJ, Xu LR, Liao JM, Chen J, Liang Y (2011) Both the C-terminal polylysine region and the farnesylation of K-RasB are important for its specific interaction with calmodulin. PLoS One 6:e21929. https:// doi.org/10.1371/journal.pone.0021929

Xu J, Haigis KM, Firestone AJ, McNerney ME, Li Q, Davis E, Chen SC, Nakitandwe J, Downing J, Jacks T, Le Beau MM, Shannon K
(2013) Dominant role of oncogene dosage and absence of tumor suppressor activity in Nras-driven hematopoietic transformation. Cancer Discov 3:993-1001. https://doi.org/10.1158/2159-8290. CD-13-0096

Yaeger R, Corcoran RB (2019) Targeting alterations in the RAF-MEK pathway. Cancer Discov 9:329-341. https://doi.org/10.1158/21598290.CD-18-1321

Yang IS, Kim S (2018) Isoform specific gene expression analysis of KRAS in the prognosis of lung adenocarcinoma patients. BMC Bioinformatics 19:40. https://doi.org/10.1186/s12859-018-2011-y

Yuan J, Ng WH, Lam PYP, Wang Y, Xia H, Yap J, Guan SP, Lee ASG, Wang M, Baccarini M, Hu J (2018) The dimer-dependent catalytic activity of RAF family kinases is revealed through characterizing their oncogenic mutants. Oncogene 37:5719-5734. https://doi.org/ 10.1038/s41388-018-0365-2

Zaballos MA, Acuna-Ruiz A, Morante M, Crespo P, Santisteban P (2019) Regulators of the RAS-ERK pathway as therapeutic targets in thyroid cancer. Endocr Relat Cancer 26:R319-R344. https://doi. org/10.1530/ERC-19-0098

Zeng M, Xiong Y, Safaee N, Nowak RP, Donovan KA, Yuan CJ, Nabet B, Gero TW, Feru F, Li L, Gondi S, Ombelets LJ, Quan C, Janne PA, Kostic M, Scott DA, Westover KD, Fischer ES, Gray NS (2020) Exploring targeted degradation strategy for oncogenic KRAS(G12C). Cell Chem Biol 27(19-31):e16. https://doi.org/10. 1016/j.chembiol.2019.12.006

Zhang Z, Wang Y, Vikis HG, Johnson L, Liu G, Li J, Anderson MW, Sills RC, Hong HL, Devereux TR, Jacks T, Guan KL, You M (2001) Wildtype Kras2 can inhibit lung carcinogenesis in mice. Nat Genet 29:25-33. https://doi.org/10.1038/ng721

Zhang M, Jang H, Gaponenko V, Nussinov R (2017) Phosphorylated calmodulin promotes $\mathrm{PI} 3 \mathrm{~K}$ activation by binding to the $\mathrm{SH} 2$ domains. Biophys J 113:1956-1967. https://doi.org/10.1016/j.bpj. 2017.09.008

Zhang M, Li Z, Wang G, Jang H, Sacks DB, Zhang J, Gaponenko V, Nussinov R (2018) Calmodulin (CaM) activates PI3Kalpha by targeting the "soft" CaM-binding motifs in both the $\mathrm{nSH} 2$ and cSH2 domains of p85alpha. J Phys Chem B 122:11137-11146. https://doi.org/10.1021/acs.jpcb.8b05982

Zhang M, Jang H, Nussinov R (2020) PI3K inhibitors: review and new strategies. Chem Sci 11:5855-5865. https://doi.org/10.1039/ d0sc01676d

Zhang M, Jang H, Li Z, Sacks DB, Nussinov R (2021) B-Raf autoinhibition in the presence and absence of 14-3-3. Structure. 29:768-777. https://doi.org/10.1016/j.str.2021.02.005

Zhou Y, Hancock JF (2015) Ras nanoclusters: Versatile lipid-based signaling platforms. Biochim Biophys Acta 1853:841-849. https://doi. org/10.1016/j.bbamcr.2014.09.008

Zhou B, Der CJ, Cox AD (2016) The role of wild type RAS isoforms in cancer. Semin Cell Dev Biol 58:60-69. https://doi.org/10.1016/j. semcdb.2016.07.012

Zhou Y, Prakash P, Gorfe AA, Hancock JF (2018) Ras and the plasma membrane: a complicated relationship. Cold Spring Harb Perspect Med 8:a031831. https://doi.org/10.1101/cshperspect.a031831

Zhou M, Kuruvilla L, Shi X, Viviano S, Ahearn IM, Amendola CR, Su W, Badri S, Mahaffey J, Fehrenbacher N, Skok J, Schlessinger J, Turk BE, Calderwood DA, Philips MR (2020) Scaffold association factor $\mathrm{B}$ (SAFB) is required for expression of prenyltransferases and RAS membrane association. Proc Natl Acad Sci U S A 117:31914 31922. https://doi.org/10.1073/pnas.2005712117

Publisher's note Springer Nature remains neutral with regard to jurisdictional claims in published maps and institutional affiliations. 